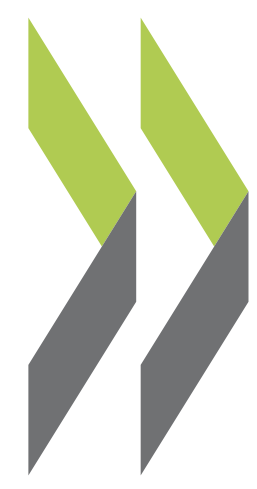

OECD Economics Department Working Papers No. 1438

Naomitsu Yashiro,

Koen De Backer,

Moving up the global value chain in Latvia
Andrés Fuentes Hutfilter,

Marco Kools,

Zuzana Smidova 
Organisation de Coopération et de Développement Économiques

Organisation for Economic Co-operation and Development

21-Nov-2017

ECONOMICS DEPARTMENT

English - Or. English

MOVING UP THE GLOBAL VALUE CHAIN IN LATVIA

ECONOMIC DEPARTMENT WORKING PAPERS No. 1438

By Naomitsu Yashiro, Koen de Backer, Andrés Fuentes Hutfilter, Marco Kools and Zuzana Smidova

OECD Working Papers should not be reported as representing the official views of the OECD or of its member countries. The opinions expressed and arguments employed are those of the author(s).

Authorised for publication by Alvaro Pereira, Director, Country Studies Branch, Economics Department.

All Economics Department Working Papers are available at www.oecd.org/eco/workingpapers.

JT03423352

This document, as well as any data and map included herein, are without prejudice to the status of or sovereignty over any territory, to the delimitation of international frontiers and boundaries and to the name of any territory, city or area. 
OECD Working Papers should not be reported as representing the official views of the OECD or of its member countries. The opinions expressed and arguments employed are those of the author(s).

Working Papers describe preliminary results or research in progress by the author(s) and are published to stimulate discussion on a broad range of issues on which the OECD works.

Comments on Working Papers are welcomed, and may be sent to OECD Economics Department, 2 Rue André-Pascal, 75775 Paris Cedex 16, France, or by e-mail to eco.contact@ oecd.org.

All Economics Department Working Papers are available at. www.oecd.org/eco/workingpapers

This document and any map included herein are without prejudice to the status of or sovereignty over any territory, to the delimitation of international frontiers and boundaries and to the name of any territory, city or area.

The statistical data for Israel are supplied by and under the responsibility of the relevant Israeli authorities. The use of such data by the OECD is without prejudice to the status of the Golan Heights, East Jerusalem and Israeli settlements in the West Bank under the terms of international law.

\section{(C) OECD (2017)}

You can copy, download or print OECD content for your own use, and you can include excerpts from OECD publications, databases and multimedia products in your own documents, presentations, blogs, websites and teaching materials, provided that suitable acknowledgment of OECD as source and copyright owner is given. All requests for commercial use and translation rights should be submitted to rights@oecd.org 


\section{ABSTRACT/RÉSUMÉ}

\section{Moving up the global value chain in Latvia}

Stronger integration in global value chains would speed up economic convergence to advanced OECD economies and raise living standards. Participation in global value chains (GVCs) offers opportunities for boosting productivity through knowledge transfer and intensive use of technologically advanced inputs. It also enables Latvia to diversify exports into high value added goods and services. Latvia's participation in GVC lags behind its Baltic and Central European peers. It also draws less value added from GVCs compared to many OECD economies. Nevertheless, GVC participation boosts the productivity of Latvian firms and enables them to increase employment and wages. Strong skills, high innovation capabilities and efficient resource allocation are essential for Latvian firms to engage in more knowledge intensive activities within GVCs. Improving access to higher education, promoting innovation cooperation between Latvian firms and foreign research institutes, reducing the large informal economy and establishing an effective judiciary and insolvency regime would unlock productivity growth through stronger integration in GVCs.

This Working Paper relates to the 2017 OECD Economic Survey of Latvia. (www.oecd.org/eco/surveys/economic-survey-latvia.htm).

JEL codes: JEL: F12 F43 O38

Keywords: global value chains, innovation, education

$* * * * *$

\section{Monter en gamme dans la chaîne de valeur mondiale en Lettonie}

Une intégration plus solide dans les chaînes de valeur mondiales permettrait d'accélérer la convergence économique avec les économies avancées de l'OCDE et de relever les niveaux de vie. En effet, la participation aux chaînes de valeur mondiales (CVM) offre des possibilités de réaliser des gains de productivité grâce aux transferts de technologies et au recours intensif à des intrants technologiquement avancés qui l'accompagnent. Elle permet aussi à la Lettonie de diversifier ses exportations au profit de biens et de services à forte valeur ajoutée. Actuellement, la participation de la Lettonie aux CVM est inférieure à celle des pays comparables de la région de la Baltique et d'Europe centrale. En outre, la Lettonie retire moins de valeur ajoutée des CVM que de nombreuses économies de l'OCDE. Cela étant, la participation aux CVM est bénéfique pour la productivité des entreprises lettones et leur permet d'augmenter l'emploi et les salaires. Des compétences élevées, de fortes capacités d'innovation et une allocation efficiente des ressources sont essentielles pour que les entreprises lettones puissent s'engager dans des activités à plus forte intensité de connaissances au sein des CVM. Améliorer l'accès à l'enseignement supérieur, promouvoir la coopération au service de l'innovation entre les entreprises lettones et les établissements de recherche étrangers, réduire la taille de l'économie informelle, actuellement importante, et mettre en place un système judiciaire et un régime de faillite efficaces sont autant de mesures qui permettraient de déverrouiller la croissance de la productivité par une plus forte intégration dans les CVM.

Ce Document de travail se rapporte à l'Étude économique de l'OCDE de la Lettonie 2017

(http://www.oecd.org/fr/economie/etude-economique-lettonie.htm)

JEL codes: JEL: F12 F43 O38

Keywords: Chêne de valeur mondiale, innovation, éducation 


\section{TABLE OF CONTENTS}

Stronger integration into global value chains can boost growth and raise living standards ......................6

Participation in global value chains has improved, still it lags behind peers ......................................9

Latvia is making little use of imported inputs in producing its exports ...............................................10

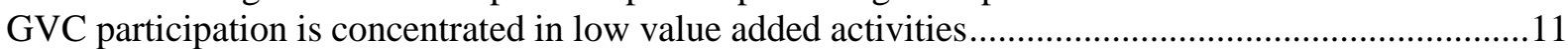

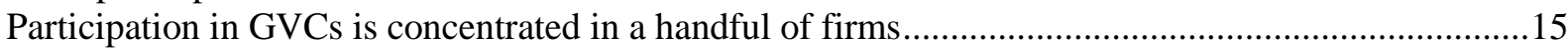

Only the most productive firms can start exporting and participate in GVC .....................................17

Participation in GVCs increases productivity, employment and wages...............................................19

Policies that boost skills, innovation and resource allocation foster inclusive participation in GVCs ......20

Improving access to higher education and lifelong upskilling opportunities .......................................20

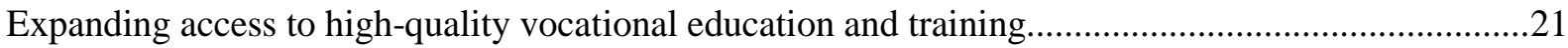

Making the most of ongoing improvements in higher education ........................................................22

Promoting adult learning and education is important especially among low skilled workers ..............23

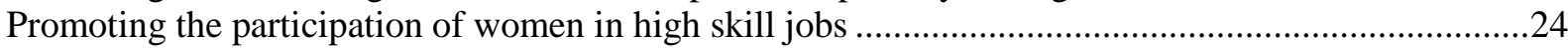

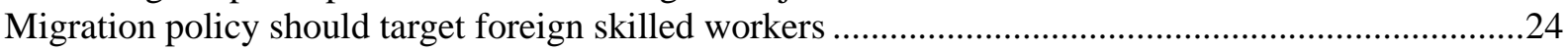

Boosting knowledge transfer and innovation capabilities of Latvian firms ..........................................25

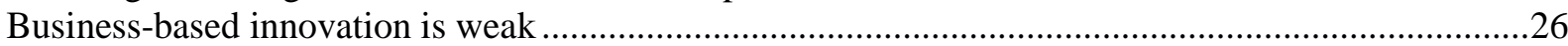

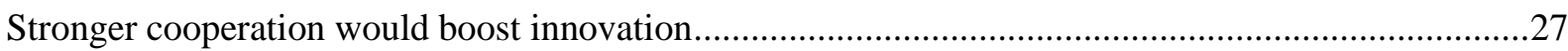

Improving resource allocation by enhancing the efficiency of the judiciary .....................................28

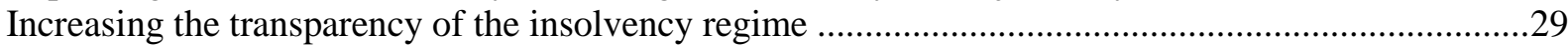

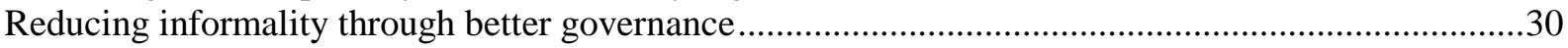

Creating a more open and competition-friendly regulatory environment ............................................32

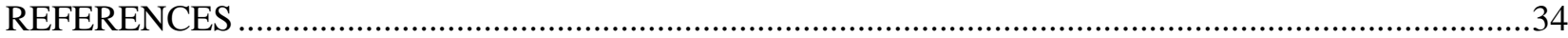

\section{Tables}

Table 1. Productivity is very low in many non-exporting firms

\section{Figures}

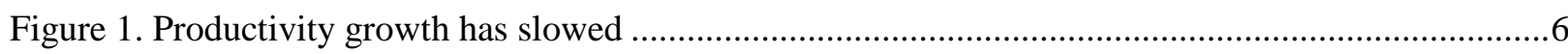

Figure 2. Latvia has room to boost productivity through trade and FDI ..............................................

Figure 3. Exports are still concentrated in resource-intensive goods and transport services ......................7

Figure 4. Latvia's export products differ substantially from advanced OECD economies .........................8

Figure 5. FDI is concentrated in sectors with low knowledge-intensity .............................................

Figure 6. Participation in GVCs has improved, but it is mainly concentrated to traditional sectors ...........9

Figure 7. Latvia's use of imported inputs is relatively low and concentrated in low-tech industries........10

Figure 8. GVC participation sustains about one-third of employment in Latvia....................................11

Figure 9. Latvia is drawing little value-added from GVC participation .................................................12

Figure 10. Value added are small in industries where larger employment is sustained by GVCs.............13

Figure 11. The skill and knowledge intensities of GVC participation are modest ..................................13

Figure 12. Value chain activities and associated value added in Latvia ................................................14

Figure 13. Only a handful of Latvian firms export .............................................................................17

Figure 14. Exporting firms are more productive, especially those participating in GVCs ......................18 
Figure 15. Exporting raises productivity, employment and wages of Latvian firms .............................19

Figure 16. The incidence of under-skilling is high while over-skilling is rare .......................................21

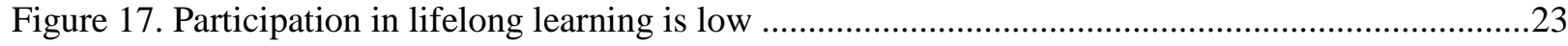

Figure 18. Low educated employees face particularly large skills gaps .............................................24

Figure 19. Latvia is not attracting highly educated immigrants..........................................................25

Figure 20. Research and development expenditure is among the lowest in the OECD..........................26

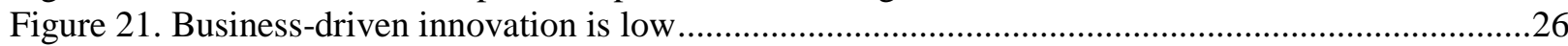

Figure 22. Cooperation with higher education or research institutions in innovation is low....................27

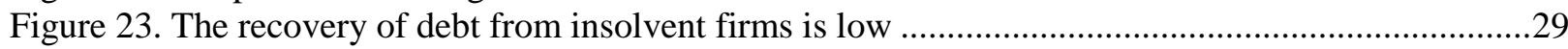

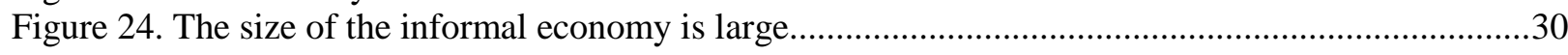

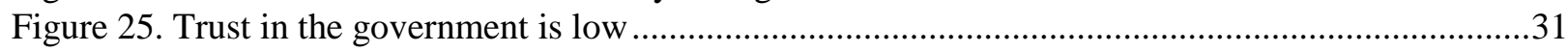

Figure 26. Barriers to service trade are low overall .............................................................................3

\section{Boxes}

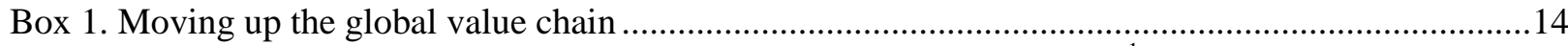

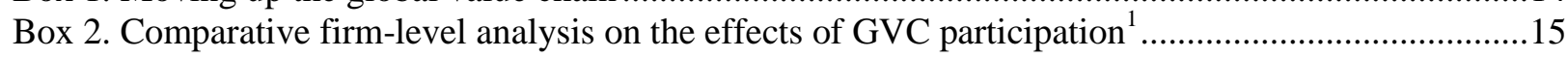

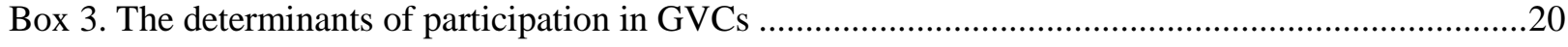




\title{
MOVING UP THE GLOBAL VALUE CHAIN IN LATVIA
}

\author{
By Naomitsu Yashiro, Koen de Backer, Andrés Fuentes Hutfilter, Marco Kools, Zuzana Smidova ${ }^{1}$
}

\section{Stronger integration into global value chains can boost growth and raise living standards}

Productivity growth is the main driver of Latvia's convergence in living standards to advanced OECD countries (OECD, 2017). Latvia enjoyed strong productivity growth until the early 2000s. However, as in many OECD countries, productivity growth has slowed significantly in the past decade (Figure 1). Reinvigorating the productivity of Latvian firms is key for raising living standards further.

\section{Figure 1. Productivity growth has slowed}

Average annual growth of labour productivity ${ }^{1}$

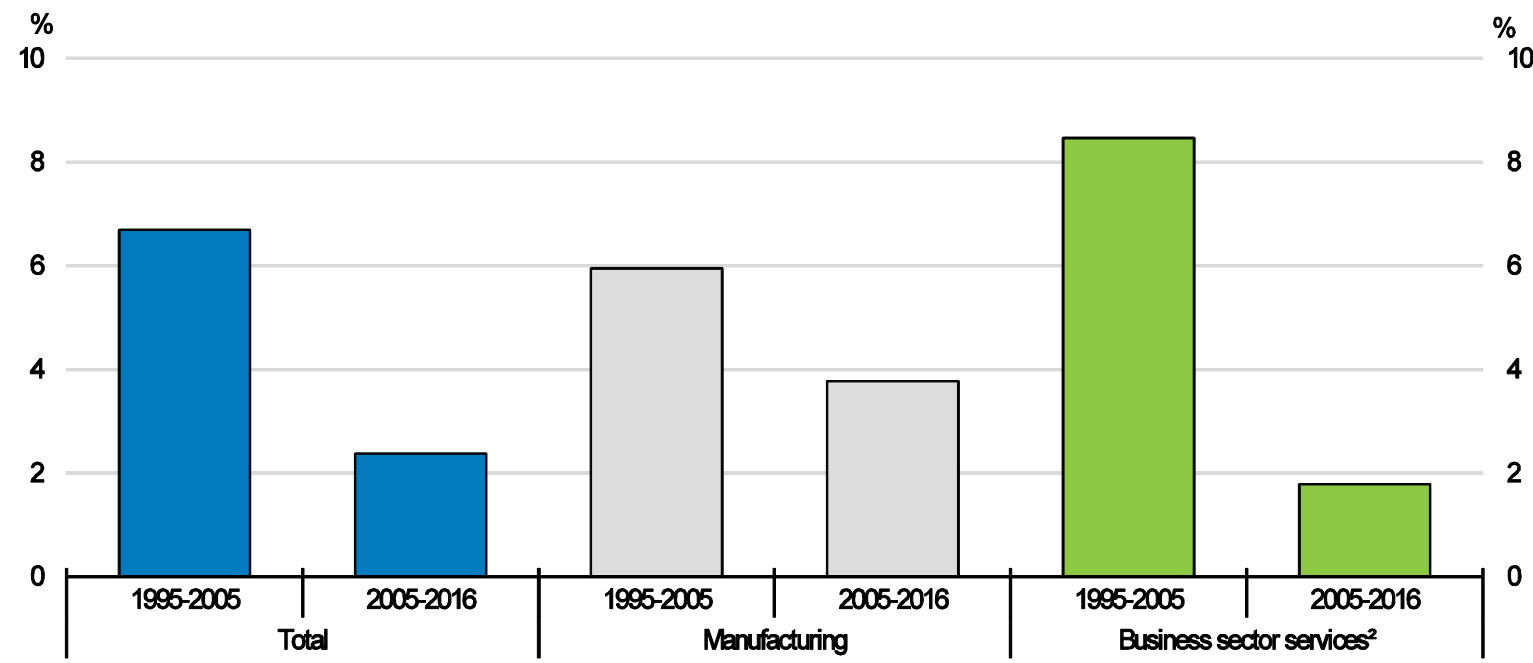

1. Labour productivity growth is the change in gross value added per hour worked at constant price.

2. Excludes real estate.

Source: OECD (2017), OECD Productivity Statistics (database).

As a small open economy, Latvia needs to be integrated into the global economy to boost productivity. International trade and foreign direct investment (FDI) channel knowledge transfer from advanced economies (Coe et al., 2009; Alfaro, 2016). Access to export markets stimulates investment in new technologies and skills by increasing the return firms can appropriate from such investment (Aw et al., 2007; Bustos, 2012). FDI by multinational enterprises provides opportunities for local firms to benefit from transfer of advanced knowledge (Hoekman and Javorcik, 2006). Yet, Latvia's foreign trade is lower than in its Baltic or Central European peers (Figure 2, Panel A). The stock of inward FDI is also relatively low (Figure 2, Panel B).

\footnotetext{
${ }^{1}$ Naomitsu Yashiro is an Economist in the Country Studies Branch of the Economics Department of the OECD and is the corresponding author; e-mail: naomitsu.yashiro@oecd.org. Koen de Backer is a Senior Economist at the Directorate for Science, Technology and Innovation. Andrés Fuentes Hutfilter is a Senior Economist in the Country Studies Branch of the Economics Department. Marco Kools is an Economist at the Education Directorate. Zuzana Smidova is an Economist in the Policy Studies Branch of the Economics Department. The report benefited from contributions from Eun Jung Kim (the Economics Department) and Norihiko Yamano (the Directorate for Science, Technology and Innovation) and valuable comments from Asa Johansson and Mathilde Pak as well as editorial assistance by Dacil Kurzweg (all from the OECD Economics Department).
} 
Latvia's export mix limits the scope of knowledge transfer and productivity growth through higher trade exposure. Although Latvia's exports are diversifying, close to $60 \%$ of goods exports are still raw materials and natural-resource intensive products (Figure 3, Panel A). The share of machinery exports has grown but about a half are re-exports (Benkkovskis et al., 2016). Latvia's goods exports are also concentrated on products that compete little with exports of advanced OECD economies (Figure 4). Transit transport and tourism account for close to 60\% of service exports (Figure 3, Panel B). Overall, Latvia's export sectors have a relatively small potential for innovation and rapid technological progress.

Figure 2. Latvia has room to boost productivity through trade and FDI

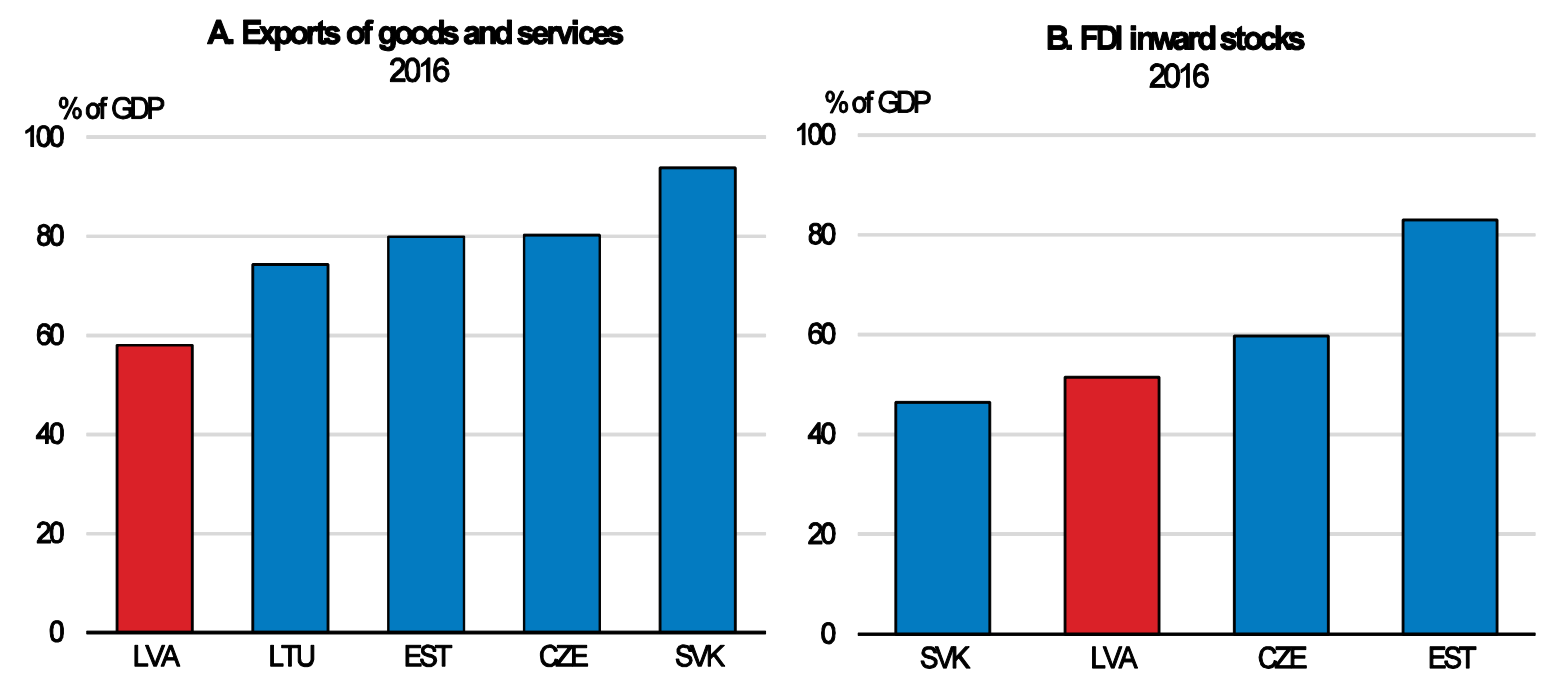

Source: OECD (2017), OECD Economic Outlook: Statistics and Projections (database) and OECD International Direct Investment Statistics (database).

Figure 3. Exports are still concentrated in resource-intensive goods and transport services

\section{A. Composition of good exports}

$\%$ of total merchandise exports

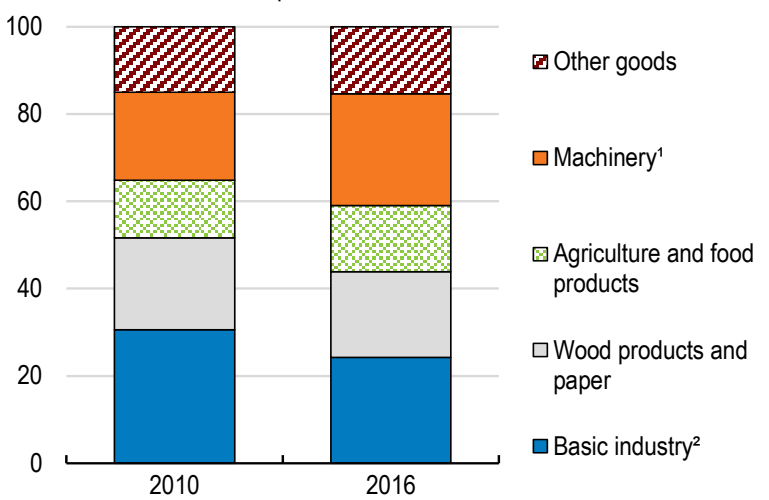

B. Composition of service exports

$\%$ of total service exports

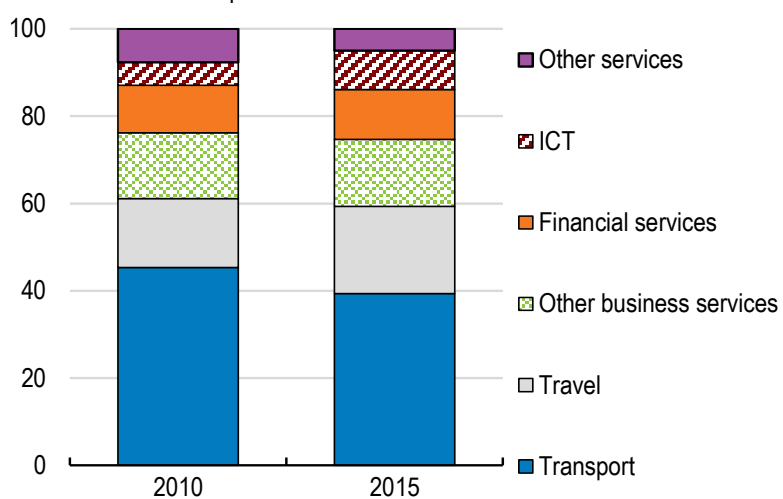

1. Includes mechanical appliances; electrical equipment; transport vehicles; optical instruments and apparatus (inc. medical); clocks and watches; musical instruments.

2. Includes products of the chemical and allied industries; plastics and articles thereof; rubber and articles thereof; base metals and articles of base metals; and mineral products.

Source: OECD (2017), Central Statistical Bureau of Latvia. 
Figure 4. Latvia's export products differ substantially from advanced OECD economies Share of export by complexity quartile

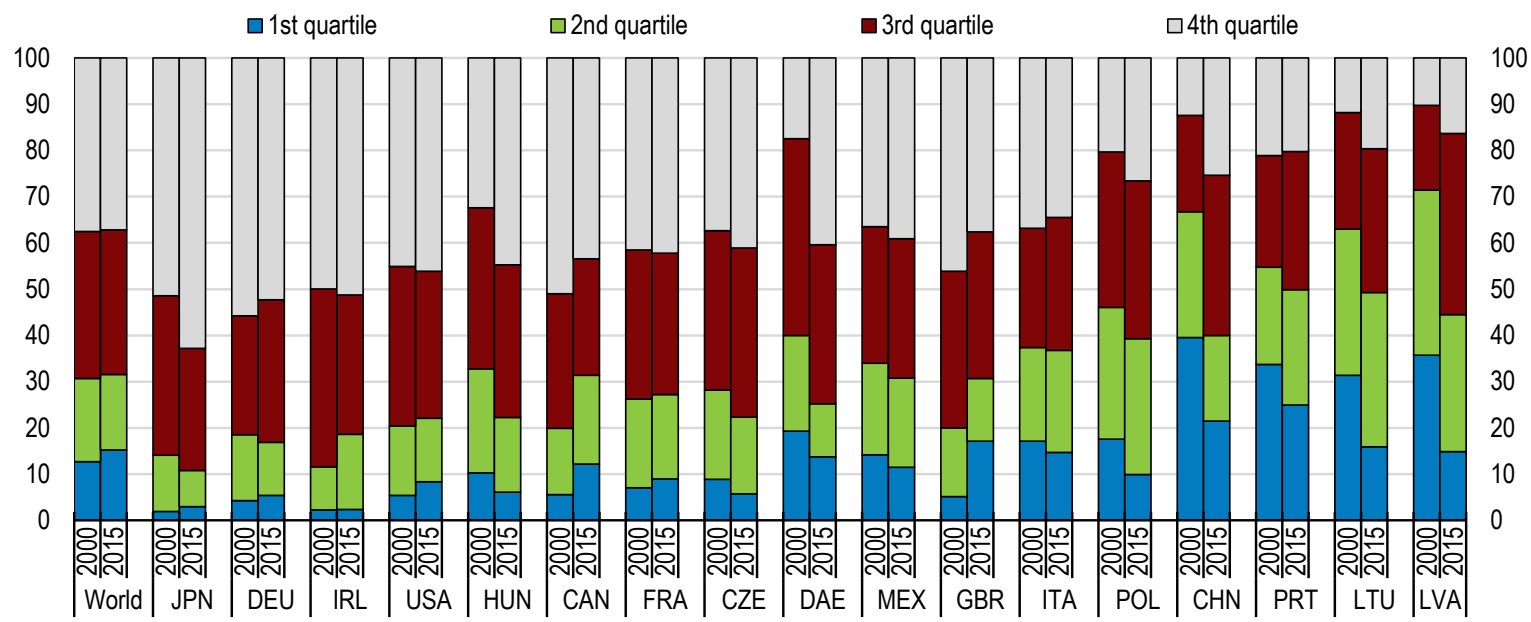

Note: Complexity is defined by the implied productivity of the product (PRODY) using the methodology of Hausmann, R., J. Hwang and D. Rodrik (2007), "What you export matters", Journal of Economic Growth, Springer, vol. 12(1). PRODY is calculated by taking a weighted average of the per capita GDPs of the countries that export the product. The weights are the revealed comparative advantage of each country in that product. The products are then ranked according to their PRODY level. An example of product in the 4th (highest) quartile is magnetic imaging resonance (MRI) machines used in scans in hospitals which ranked 18th in 2015, out of 4989 products listed in the Harmonized System 6 classification. A product in the 1st (lowest) quartile is crayons ranked 4218th in 2015. The analysis is carried out using a high level of product disaggregation to try to capture specialisation at different stages of the production chain. Source: Araujo, S., T. Chalaux and D. Haugh (2017), "Who's in Your Export Market? The Changing Pattern of World Trade in the Age of GVCs", OECD Economics Department Working Papers, forthcoming.

While Latvia receives FDI predominantly from technologically advanced OECD countries (Figure 5, Panel A), FDI is concentrated in sectors with relatively low knowledge intensity, limiting the scope of knowledge transfer. About $40 \%$ of employment in multinational enterprises (MNEs) is in transportation, storage, wholesale and retail trade (Figure 5, Panel B). Less than a quarter of MNEs' employment is in manufacturing, mostly in traditional, natural-resource intensive industries.

Figure 5. FDI is concentrated in sectors with low knowledge-intensity

The composition of employment by MNEs, 2014
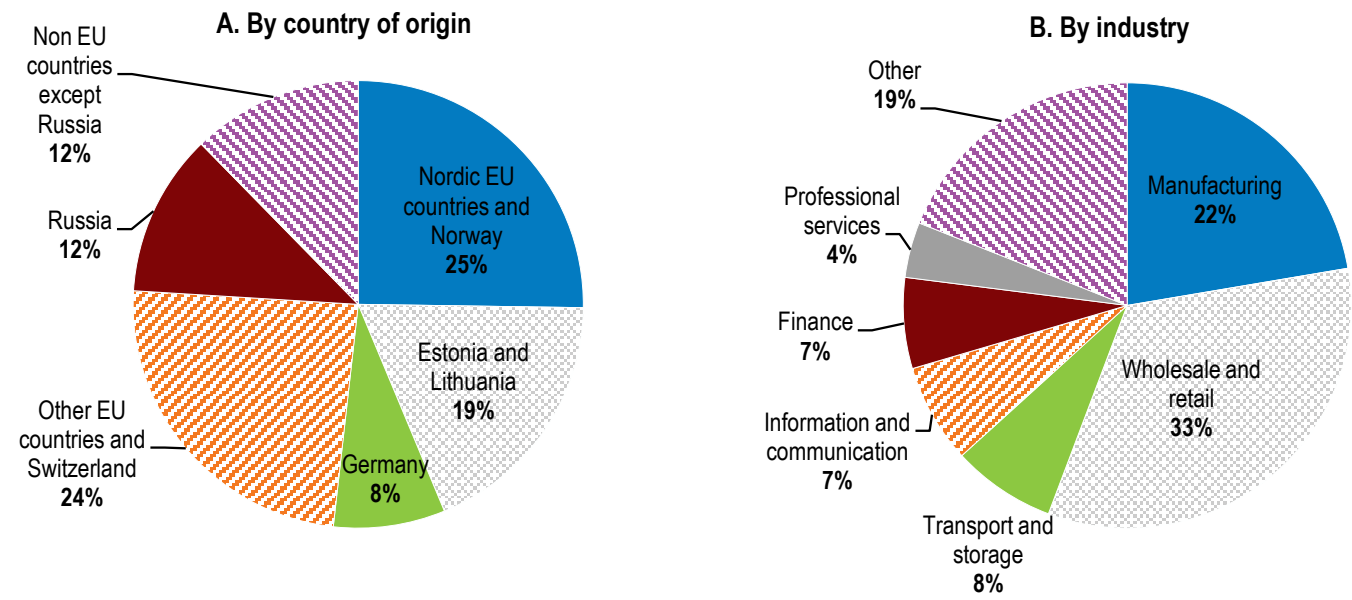

Source: OECD (2017), Activity of Multinational Enterprises Database. 


\section{Participation in global value chains has improved, still it lags behind peers}

Latvia's participation in GVCs has progressed since the crisis. Yet, it lags somewhat behind Baltic and Central European peers. The share of domestic value added embodied in foreign final demand was below 40\% in 2014. This is lower than in Estonia and other Central European countries (Figure 6, Panel A). The domestic value added embodied in foreign final demand includes exports and domestic production supplying inputs to exports, and is a measure of the extent to which Latvia participates in GVCs as a supplier.

Latvia participates in GVCs mainly as the provider of logistic services and base materials, reflecting its role as a transit hub (Figure 6, Panel B). Knowledge-intensive services such as ICT and professional services (included in real estate, renting and business activities in panel B), generate less value added than in Estonia. Also, the value added created in the manufacturing sector is smaller than in Estonia and Czech Republic. Within manufacturing, traditional industries such as wood processing and food products are generating most value added, and the role of high-technology industries is relatively small.

\section{Figure 6. Participation in GVCs has improved, but it is mainly concentrated to traditional sectors}

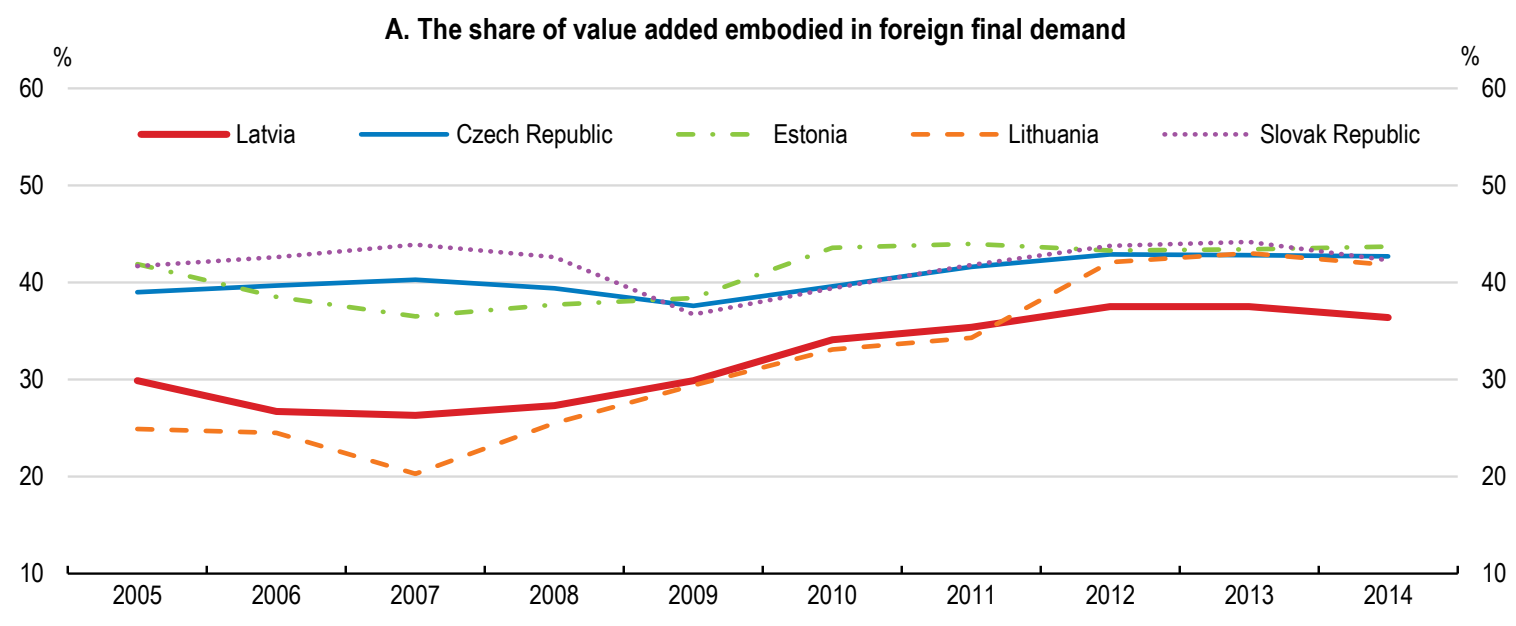

B. The sectoral decomposition of the share of value added embodied in foreign final demand $\%$
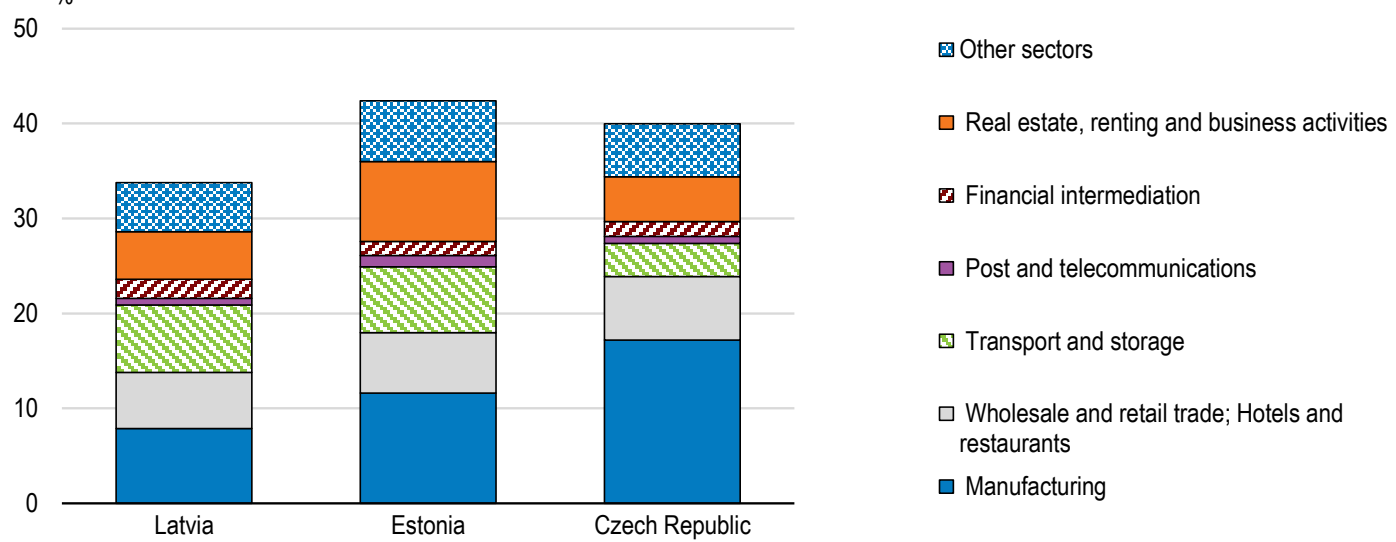

Note: Panel A displays the share of domestic value added that are embodied in the foreign final demand in total domestic value added. The data after 2011 are estimates based on the 2011 Inter-Country Input-Output (ICIO) table and the OECD Bilateral Trade Database by Industry and End-Use (BTDIxE). Panel B is a sectoral break down of the share shown in panel A, It refers to the 2011 data.

Source: OECD/WTO (2016), Statistics on Trade in Value Added (database), and OECD calculations based on OECD/WTO (2016), Statistics on Trade in Value Added (database) and OECD (2016), OECD National Accounts Statistics (database). 


\section{Latvia is making little use of imported inputs in producing its exports}

Participation in GVCs is often associated with an intensive use of technologically-advanced imported inputs, which is an important driver of productivity growth. The use of imported inputs enables countries to diversify exports, upgrade product quality and absorb the knowledge embodied in such inputs (Amiti and Koning, 2007). The share of foreign value added embodied in Latvia's exports captures the use of imported inputs to produce its exports, and thus the extent of Latvia's participation in GVCs as a user. Foreign value added accounted for around 30\% of Latvian exports in 2014, which is considerably lower than in Estonia and some Central European countries (Figure 7, Panel A).

There is scope to boost productivity growth by participating more in GVCs of high-technology goods through more intensive use of imported intermediate goods. The use of imported inputs could be particularly effective in boosting productivity growth in industries where Latvia has much potential to catch up to the technology frontier. However, the use of imported inputs in manufacturing exports is concentrated in traditional industries such as wood and food products or basic metals (Figure 7, Panel B), where this potential is small. The use of imported inputs in high-technology industries such as electric and optical equipment or transport equipment is small. This contrasts with Estonia and the Czech Republic.

Figure 7. Latvia's use of imported inputs is relatively low and concentrated in low-tech industries

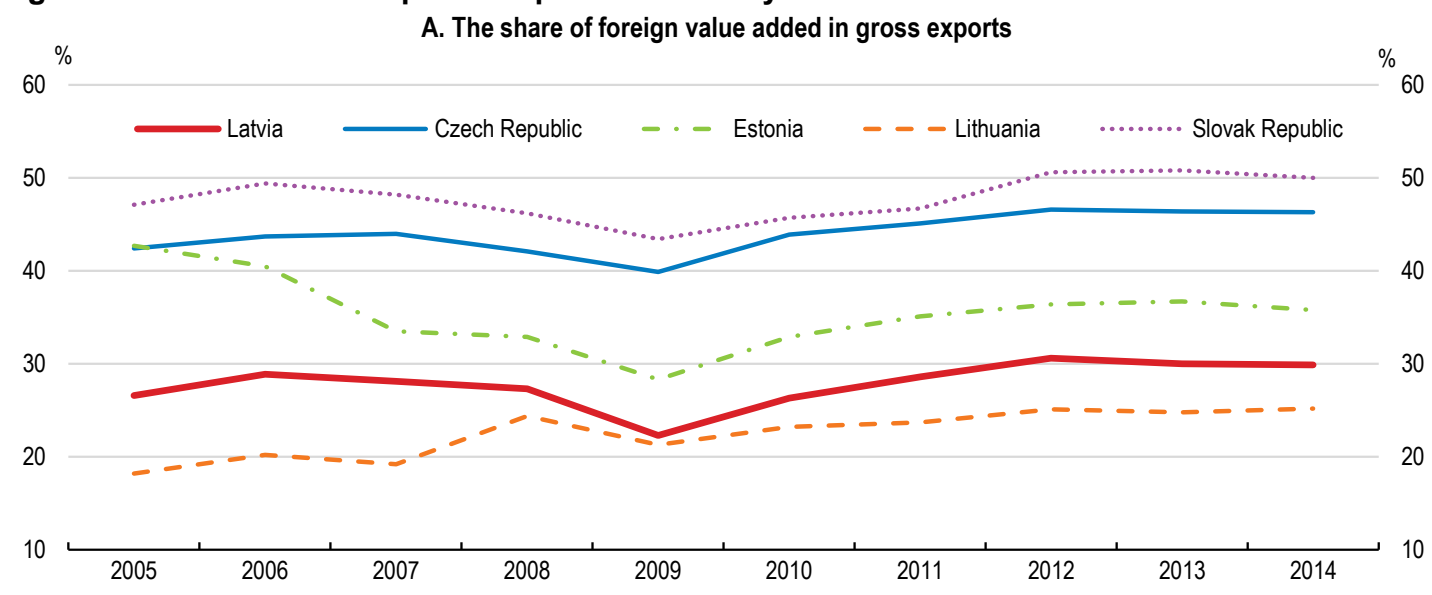

B. Industrial decomposition of the share of foreign value added in manufacturing exports $\%$
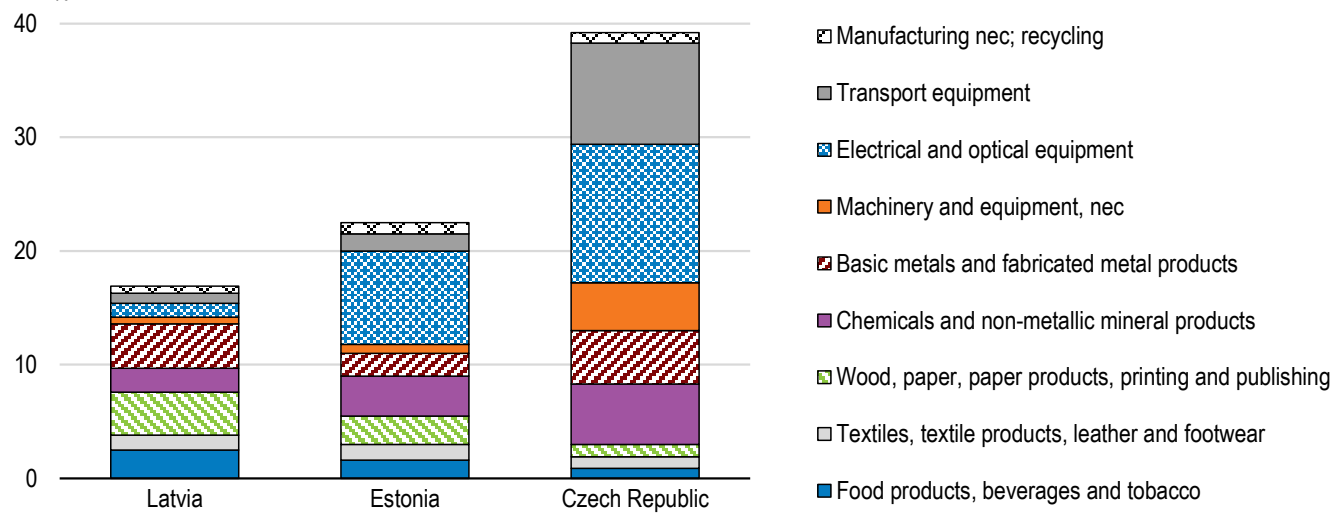

Note: Panel A displays the share of foreign value added that are embodied in the country's exports. The data after 2011 are estimates based on the 2011 Inter-Country Input-Output (ICIO) table and the OECD Bilateral Trade Database by Industry and End-Use (BTDIxE). Panel B is the breakdown of such share focusing only on the exports in manufacturing sector. It refers to 2011 data.

Source: OECD/WTO (2016), Statistics on Trade in Value Added (database), and OECD calculations based on OECD/WTO (2016), Statistics on Trade in Value Added (database) and OECD (2016), OECD National Accounts Statistics (database). 


\section{GVC participation is concentrated in low value added activities}

Participation in GVCs is an important source of employment for Latvia. About one-third of employment is sustained by foreign final demand. Yet, this is lower than in Estonia or Central European countries where participation in GVC generates more that $40 \%$ of all jobs. Foreign final demand sustains particularly large shares of employment in some manufacturing industries such as textiles, machinery and electrical equipment and in services such as transportation and storage (Figure 8).

Figure 8. GVC participation sustains about one-third of employment in Latvia

The share of employment sustained by foreign final demand, latest available year

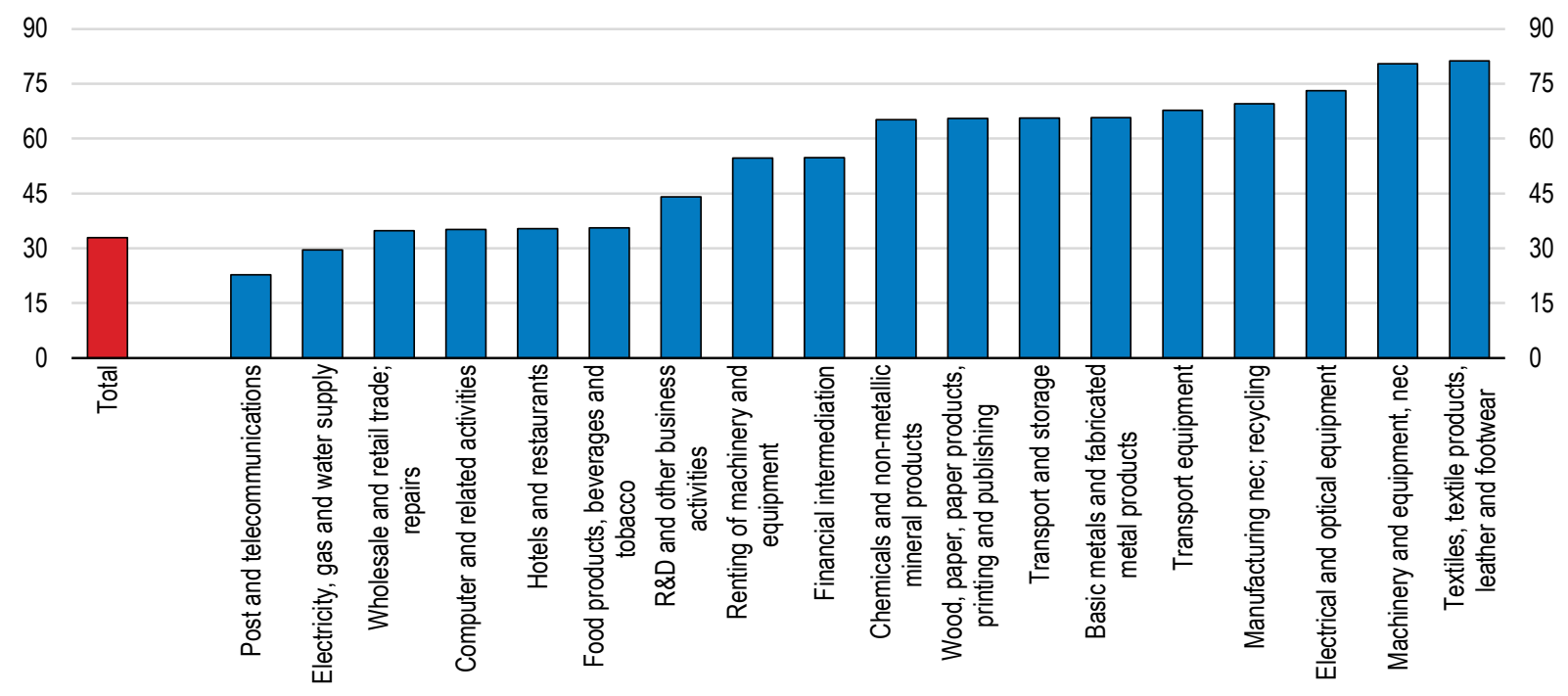

Note: Data refers to 2011.

Source: OECD (2016), "Trade in Employment: Core Indicators" in OECD Structural Analysis (STAN) Databases.

Overall, Latvia is specialised in low value added activities within GVCs. The value-added from GVC participation per worker is among the lowest in OECD countries, even lower than in Baltic and Central European peers (Figure 9, Panel A). This is particularly the case in electrical machinery (Figure 9, Panel B). This suggests that Latvia is mainly engaging in less knowledge intensive, most likely labour intensive activities. In wood products, Latvia is drawing higher value added from GVC participation compared to its peers (Figure 9, Panel C). However, the amount of value added that the most remunerated countries draw from GVC in wood products is markedly smaller than that in electrical machinery. Shifting GVC participation to activities and industries that generate higher value added would support stronger productivity growth.

The value added drawn from GVC participation tends to be particularly low in industries where the share of employment is sustained by GVC participation is large (Figure 10). It is essential that Latvia engages more in knowledge-intensive activities that yield higher value added to boost productivity growth and create more high-skilled jobs. Such activities include new product development, manufacturing of technologically advanced components, as well as knowledge intensive services including marketing and branding (see Box 1). Strengthening innovation capabilities and investing in advanced technologies, skills and superior management practice would improve the comparative advantage in such activities (OECD, 2013b). 
Figure 9. Latvia is drawing little value-added from GVC participation

Value added embodied in foreign final demand per worker

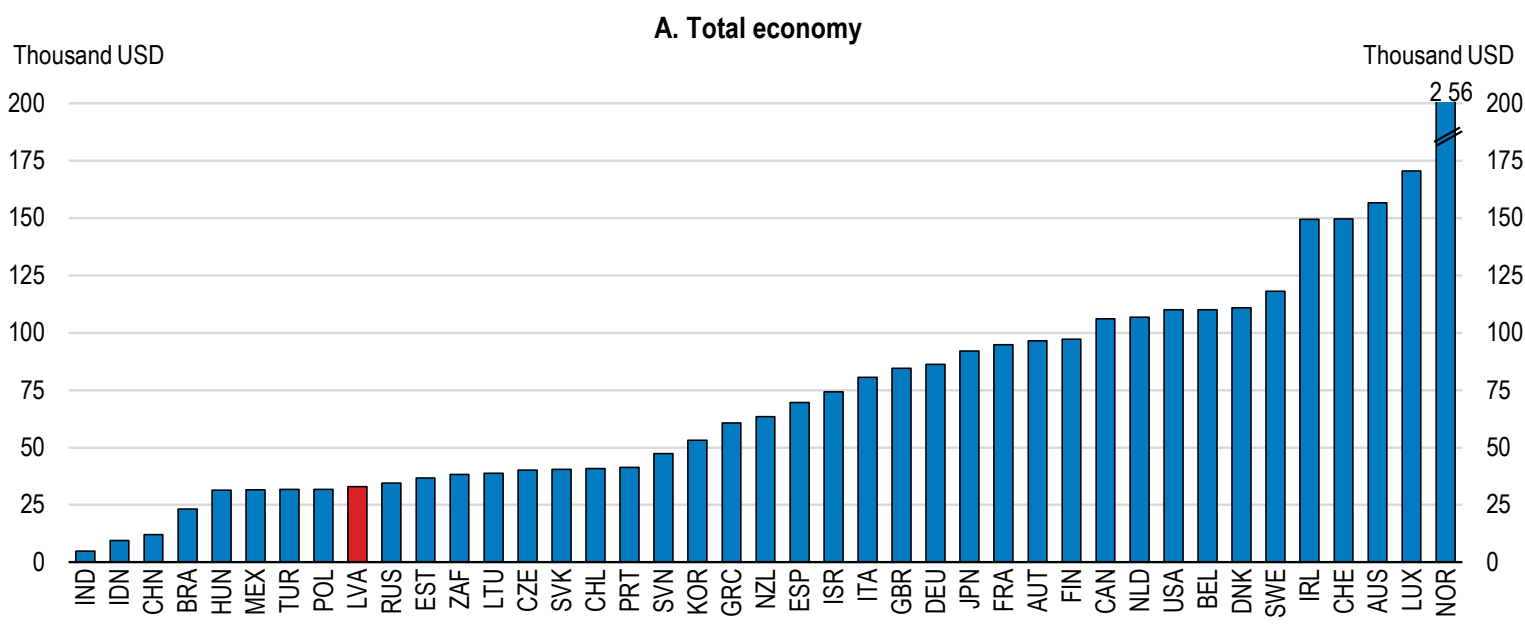

B. Electrical and optical equipment

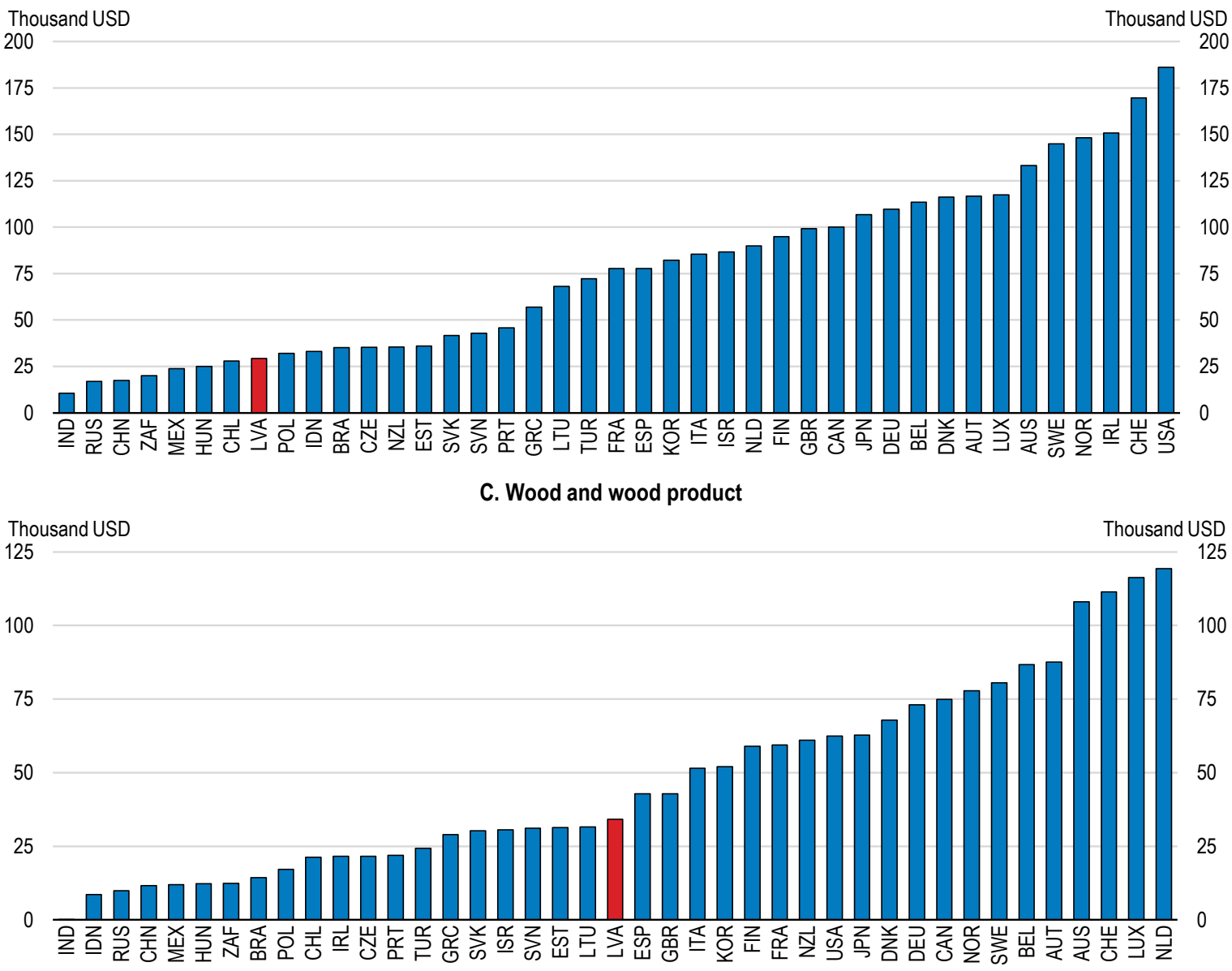

Note: Value added embodied in foreign final demand per worker is computed by dividing the domestic value added embodied in foreign final demand by the number of employment sustained by foreign final demand. Data refers to 2011.

Source: OECD/WTO (2016), Statistics on Trade in Value Added (database) and OECD (2016), "Trade in Employment: Core Indicators" in OECD Structural Analysis (STAN) Databases. 
Figure 10. Value added are small in industries where larger employment is sustained by GVCs Value added embodied in foreign final demand per worker by industries

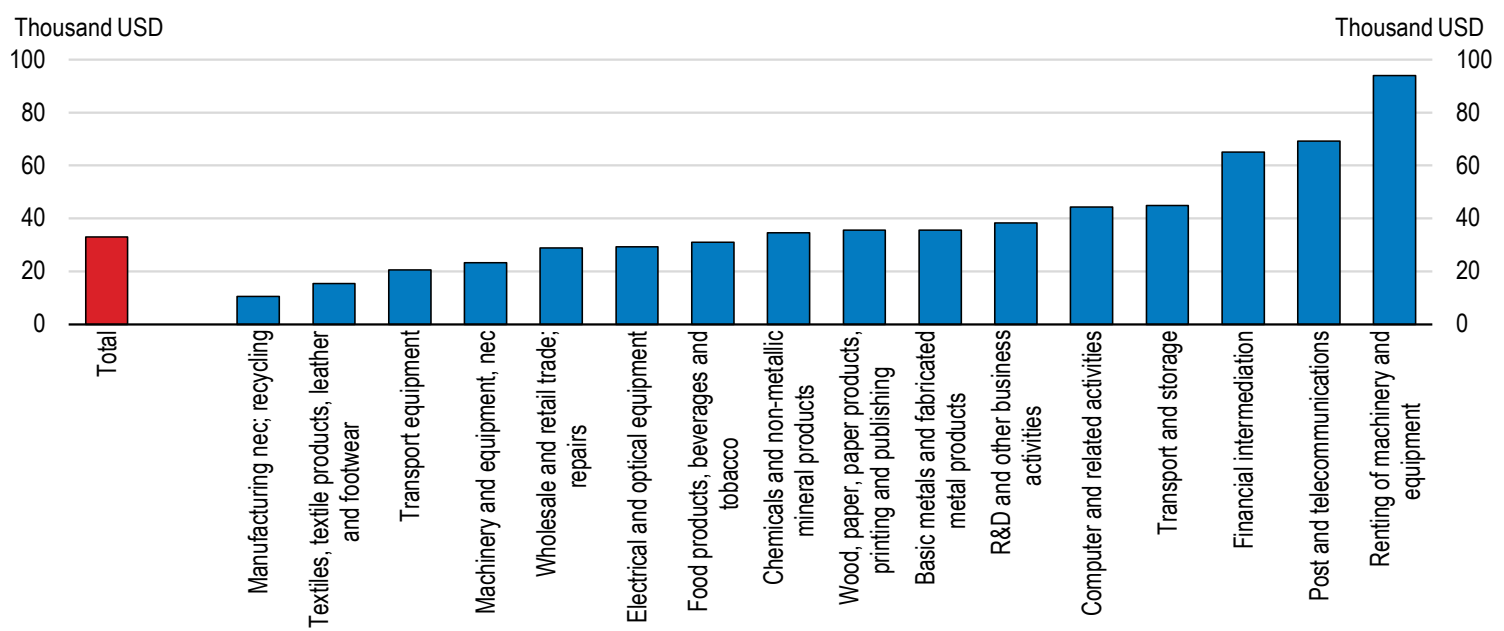

Note: Value added embodied in foreign final demand per worker is computed by dividing the domestic value added embodied in foreign final demand by the number of employment sustained by foreign final demand. Data refers to 2011.

Source: OECD/WTO (2016), Statistics on Trade in Value Added (database) and OECD (2016), "Trade in Employment: Core Indicators" in OECD Structural Analysis (STAN) Databases.

Latvia's participation in GVCs has potential to become more skill and knowledge intensive. The share of high skilled jobs (e.g. managers, professionals and technicians) out of all jobs sustained by foreign final demand is higher in Latvia than in Baltic and central European peers (Figure 11, Panel A). It is however possible that many of those skilled personals are hired in low technology sectors engaging in low value added activities. Also, Latvia's exports embody a higher share of inputs from knowledge intensive services such as research and development or computing services, compared to some peers (Figure 11, Panel B). Yet the skill and knowledge intensities are still modest when compared with advanced economies that are likely to be operating the GVCs which Latvia participates. In order to move up the value chain, Latvian firms have to be able to compete with firms in advanced countries.

Figure 11. The skill and knowledge intensities of GVC participation are modest
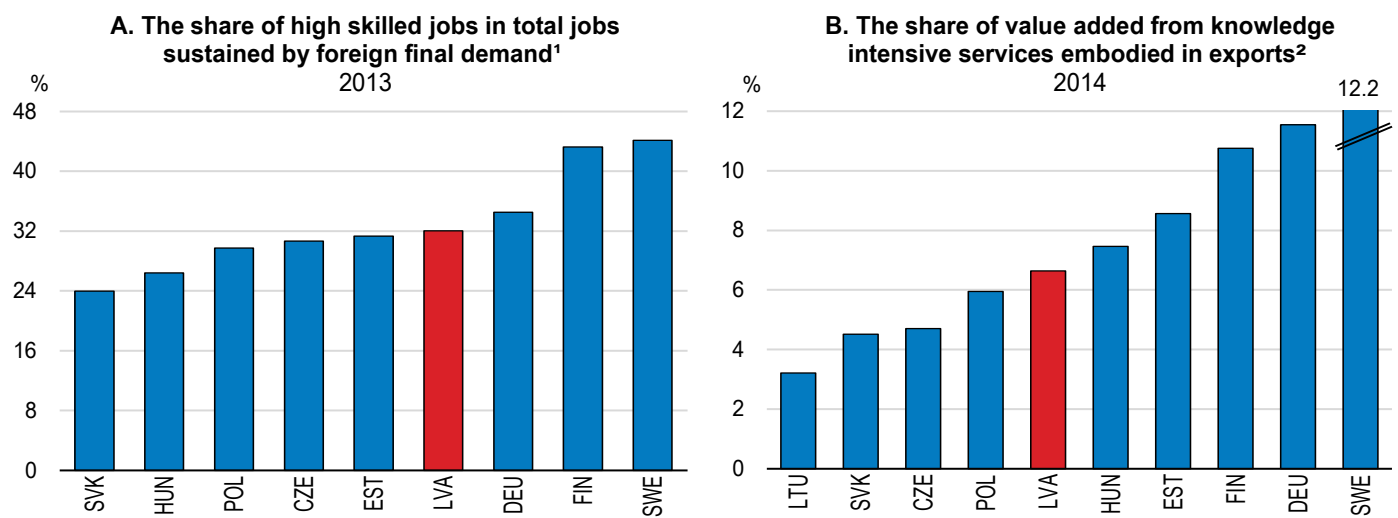

1. The figure decomposes total employment sustained by exports derived from OECD's Inter-Country Input-Output (ICIO) table into three groups of skill intensity defined according to major groups of the International Standard Classification of Occupations 2008 (ISCO-08): High-skilled occupations (ISCO-08 major Groups 1 to 3), medium-skilled (4 to 7) and low-skilled (8 and 9). OECD calculations based on the OECD Inter-Country Input-Output (ICIO) table, the OECD Bilateral Trade Database by Industry and End-Use (BTDIXE) and European Labour Force Survey (EU-LFS).

2. OECD calculations based on the OECD Inter-Country Input-Output (ICIO) table and the OECD Bilateral Trade Database by Industry and End-Use (BTDIxE).

Source: OECD/WTO (2016), Statistics on Trade in Value Added (database). 


\section{Box 1. Moving up the global value chain}

The rise of GVCs shifts the policy focus from competitiveness in strategic industries to competitiveness in value chain activities that yields particularly high value added.

Figure 12. Value chain activities and associated value added in Latvia

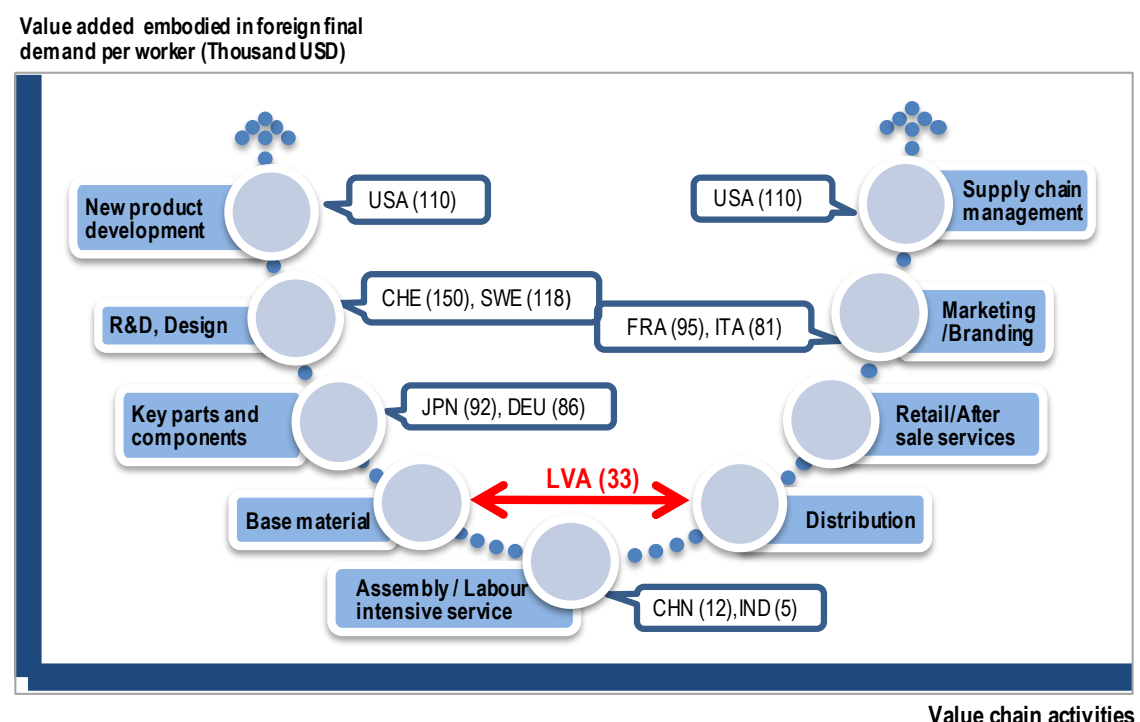

Note: The figure illustrates the value added associated with different types of value chain activities, with examples of countries with notable competitiveness in each of the different activities. Numbers in the bracket are the value added embodied in foreign final demand per worker, shown in Figure 1.8, Panel A.

Source: OECD calculations based on OECD/WTO (2016), Statistics on Trade in Value Added (database).

Within GVCs, countries that excel in knowledge- and technology intensive activities such as innovation, basic research, design or branding or those supplying key inputs that define the competitiveness of final products are remunerated much more than those providing standardised, substitutable inputs and less knowledge-intensive activities such as mass assembly (OECD, 2013a; Baldwin, 2012; Dedrick et al., 2010). The figure below illustrates the relation between the main value chain activities a country engages in and the value added it draws from GVC participation (value added embodied in foreign final demand per worker shown in Figure 1.9 Panel A). Emerging economies often enjoy a boost in productivity growth as they participate in GVCs because they access larger demand and specialise in activities they have comparative advantage. However, they are prone to be trapped in activities associated with low value-added, due to their limited innovation capabilities and knowledge-based capital (OECD, 2013a).

The above ordering of the size of value added along value chain activities is sometimes inferred as the smile curve and applies best to the GVC of electric machinery or apparel (OECD, 2013a). It is somewhat stylised, since the value added from a value chain activity is in general determined by entry barriers (Kaplinsky and Morris, 2002). Entry barriers can be institutional such as entry regulations, but are more often rooted in the difficulty to produce the knowledge-based capital that underpins the competitiveness in the specific activity (OECD, 2013a, 2013b).

There are several ways to realise higher value added from GVC participation. The following patterns have been documented in vast number of case studies (OECD, 2013a).

- Process upgrading: undertaking tasks with significantly greater efficiency and lower defect rates, and process more complex orders.

- Product upgrading: supplying higher value-added products owing to their superior technological sophistication and quality, and also introducing novel products faster. This is the case of wood products in Latvia.

- $\quad$ Functional upgrading: starting to supply competitive products or services in value chain activities which are associated with higher value added. This is the case of countries previously specialised in labor intensive activities such as assembly to start exert competitiveness in knowledge intensive activities such as R\&D or design. 
- Chain upgrading: participating in new GVCs that produce higher value-added goods or services, often leveraging the knowledge and skill acquired from the current participation in GVCs. In the case of Latvia, this means shifting the weight of its GVC participation from traditional industries to high technology industries and knowledge intensive services.

In the process of catching up to advanced economies, a country often succeeds in process upgrading as the first step of upgrading GVC activities (Gereffi, 1999). As technological capabilities improve, product upgrading follows and functional upgrading is achieved when innovation capabilities are sufficiently built up. Chain upgrading is possibly the most challenging as it requires rich accumulation of a wide range of knowledge-based capital including superior managerial know-how to identify new profitable products (OECD, 2013b).

\section{Participation in GVCs is concentrated in a handful of firms}

Considering Latvia's small domestic market size, access to foreign markets through GVCs is likely to boost Latvian firms' productivity by increasing capacity utilisation and scale economies. However, productivity growth can be long lasting if GVC participation results in qualitative changes such as the absorption of advanced technology or increase in innovation capabilities. Long-lasting productivity gains are particularly important for supporting competitiveness in the current context of strong wage growth. Relying on new firm-level empirical analysis, this section assesses the effects of GVC participation on Latvian firms' productivity, employment and wages (see Box 2).

\section{Box 2. Comparative firm-level analysis on the effects of GVC participation ${ }^{1}$}

This empirical analysis assesses the effects of participation in GVC on the performance of Latvian and Estonian firms. The research focuses on GVC participation through exports. It abstracts from other channels such as domestic transactions with MNEs, due to data constraints and also due to the low FDI penetration in Latvia.

\section{Data and approach}

The research exploits administrative firm-level datasets on corporate activities and international trade of Latvian and Estonian firms over the period 2006 to 2014 (1995 to 2014 for Estonian firms) as well as employee-employer. Data processing and empirical approaches were harmonized to the largest possible extent between the Latvian and Estonian empirical analysis to allow comparison between the two countries.

The research highlights types of exports that are closely linked to participation in GVCs, namely exports of intermediate goods, re-exports, and service export. A firm is considered to be exporting intermediate goods, if its exports goods are classified as intermediate goods according to the OECD BTDIxE end-use classification (2). This classification is used to compute the trade flow of intermediate goods across countries, the main component of the OECD-WTO Trade in Value Added (TiVA) database. Re-exports is estimated to comprise on average $28 \%$ of Latvia's merchandise exports between 2005 and 2013 (Ben,kovskis et al., 2016). Re-exports may not only include logistic services. They can also include high value-added activity that facilitates trade between parties with large information asymmetries (Feenstra and Hanson, 2004). A firm is considered to be engaging in re-exports if it imports and exports the same product within a narrowly defined classification (CN 8 digits) within 12 months (Bentkovskis et al., 2016). Service sector is observed to play a large role in GVCs. It comprises a large share in the value added created from exports (OECD, 2013a). Service inputs increasingly define the competitiveness of manufacturing as they allow firms to add higher value to their products by complementing them with knowledge-intensive services (Miroudot and Cadestin, 2016). This research distinguishes transport and non-transport service exporters, given the large weight of transport service in Latvia's exports. Exports of non-transport services include exports of knowledge intensive services such as ICT and professional services.

\section{Measuring the advantage of firms participating in GVCs}

The research employs the well-established empirical framework for comparing exporting firms with non-exporting firms (Bernard and Jensen, 1999). Firm-level performance indicators such as productivity, employment and average wage (denominated by $Y_{i j t}$ on the left hand side of the equation below) are regressed on an indicator variable that takes the value 1 if a firm $\mathrm{i}$ is an exporter and 0 otherwise (the term Exporter $_{i j t}$ on the right hand side), while 
controlling for other factors that affect performance for example, firm size, firm age, or foreign ownership (the term $X_{i j t}$ on the right hand side). Industry and year specific effects are also controlled for by including dummy variables $\eta_{j}$ and $\eta_{t}$.

$$
\ln Y_{i j t}=\alpha+\beta * \text { Exporter }_{i j t}+X_{i j t}+\eta_{j}+\eta_{t}+\varepsilon_{i j t}
$$

The coefficient $\beta$ captures the performance advantage of exporting firms over non-exporters in percent. Across countries, this coefficient is found to be positive and statistically significant (ISGEP, 2008). In this research, the indicator variable for exporting firms is replaced by several variables corresponding to the types of exports related to GVC participation described above.

\section{Evaluating the effect of GVC participation}

The key objective of the research is to evaluate whether entry to exports, especially those closely related to GVC participation, results in a significant improvement in performance. This can be inferred by observing whether firms that started exporting experience higher increase in productivity compared to those that did not. However, firms with better performance ex ante have higher chance of becoming exporters (Beṇkovskis et al., 2017). Therefore, in order to isolate the effect of exporting from such "self-selection" effect, the comparison is made between export entrants and the specific group of non-exporters that were initially as likely to start exporting as actual export entrants. The research focuses on export entrants that remain in export markets for two consecutive years after the year of export entry.

The first step is to estimate the probability for a firm to start exporting (the left hand side of the equation below) as the function of its productivity level and other factors that are likely to enable firms to overcome the initial costs of export entry (the vector $X$ on the right hand side). They include firm size, firm age, the liquidity ratio, capital labour ratio $(\mathrm{K} / \mathrm{L})$ and foreign ownership. The explanatory variables are lagged one year in order to avoid reverse causality.

$$
\operatorname{Prob}\left(\text { Export entry }_{t}\right)=f\left(\text { Productivity }_{t-1}, X_{t-1}\right)
$$

The next step is to match each export entrant with non-exporters with the closest likelihood of export entry. Then, the mean of the productivity level in s years after the export entry is compared between the group of export entrants (the first term in the equation below) and that of matched non-exporters (the second term). The difference is interpreted as the effect of export entry.

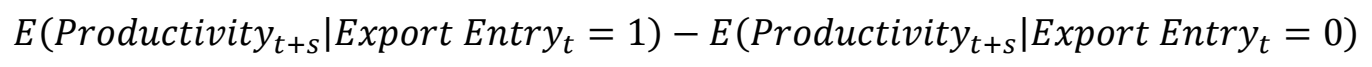

This method has been widely employed by previous studies to infer "learning by exporting," the effect of exports on productivity growth, possibly channeled by absorption of new knowledge from foreign markets (De Loecker, 2007). Supportive evidences for learning by exporting are often found for firms in developing and emerging countries but not always for those in large advanced economies (Wagner, 2007).

1. This research is joint research with the Bank of Latvia and researchers at the University of Tartu, Estonia.

2. See:http://www.oecd.org/trade/bilateraltradeingoodsbyindustryandend-usecategory.htm.

Despite the small size of the domestic market, a large majority of Latvian firms do not export. In 2014, only $6 \%$ of Latvian firms exported in 2014. Only 3\% of firms exported intermediate goods or re-exported and less than $1 \%$ of firms exported services (Figure 13). There are a large number of very small firms that do not export, which is partly due to the micro enterprise tax regime that encourages firms to split into smaller units. Among firms with more than 10 employees 28\% export. Export entry is rare. In 2014, less than $2 \%$ of firms started exporting and less than $1 \%$ of firms started exporting intermediate goods or reexporting. Only a tiny fraction of service exporters are new exporters. 
Figure 13. Only a handful of Latvian firms export

The share of exporters in the total number of Latvian firms, 2014

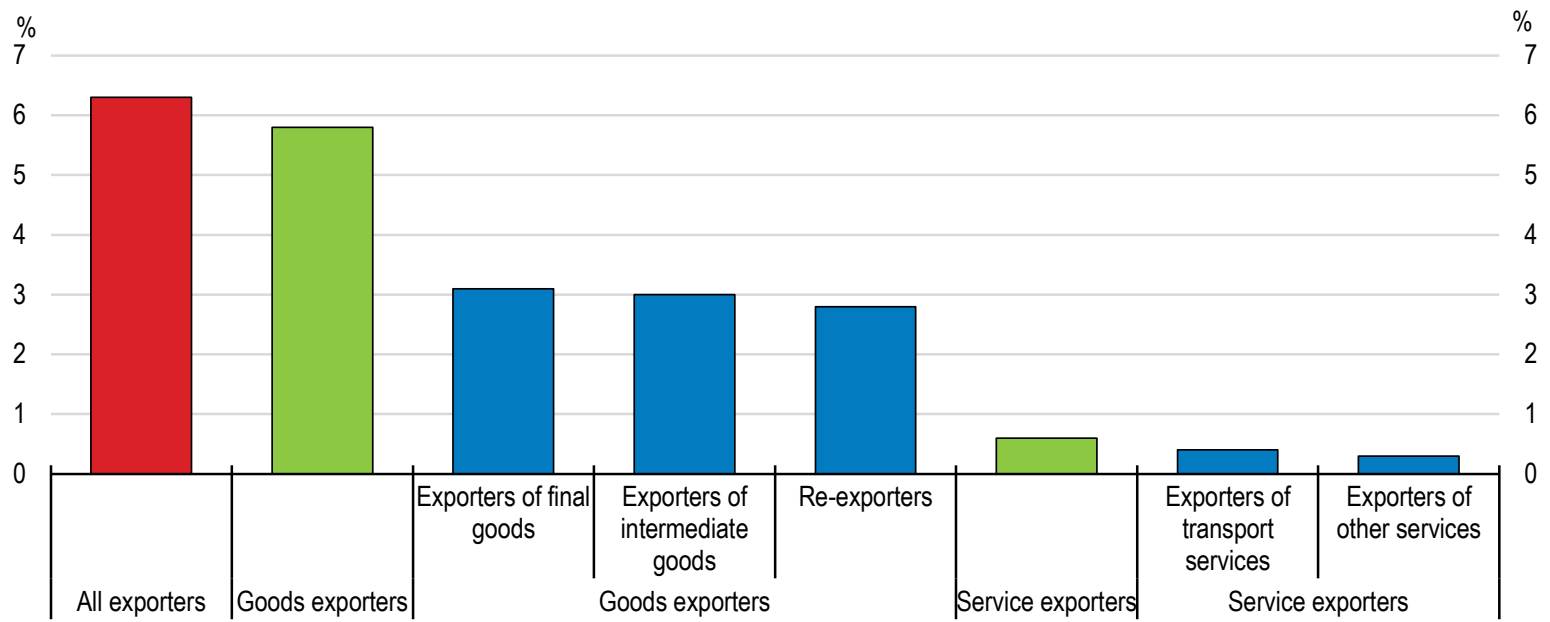

Note: The shares of different types of goods exporters add up to more than the share of all goods exporters because some goods exporters export both final and intermediate goods, or part of their exports are categorised as re-exports. Firms in agriculture and mining, energy and water supply, construction, and public services sectors are excluded.

Source: Ben,kovskis et al. (2017), "Export and productivity in Global Value Chain: Evidences from Latvian and Estonian firms" OECD Economics Department Working Paper, forthcoming.

Among the handful of firms that export, exports are highly concentrated in a few firms. For instance, the top 5\% exporters accounted for 65\% of total exports in 2014. Exports related to GVC participation such as export of intermediate goods are also concentrated to the same extent. The low share of Latvian firms participating in GVCs and the high concentration of exports related to GVC participation indicate that benefits from increased participation in GVCs is concentrate in a handful of firms.

\section{Only the most productive firms can start exporting and participate in GVC}

After controlling for the firms' age, liquidity and foreign ownership exporting firms have on average $80 \%$ higher labour productivity, employ more than twice as many workers, pay $62 \%$ higher wages and use $77 \%$ more capital per worker than non-exporting firms (Figure 14, Panel A). The advantage in labour productivity is especially large for firms engaging in exports closely related to GVC participation such as exports of intermediate goods and re-exports (Figure 14, Panel B). Service exporters have on average 90\% higher labour productivity than non-exporters. The productivity advantage is particularly large for firms exporting non-transport services. Firms which export intermediate goods and non-transport services are likely to participate in the upstream or far-downstream of GVCs. This generates higher value added (see Figure 12 in Box 1).

These significant advantages of exporting firms over non-exporting firms partly exist because firms that start exporting are originally more productive and larger than those that do not (Bernard and Jensen, 1999). This is because export entry requires significant costs to penetrate foreign markets (Roberts and Tybout, 1997). Only firms that are productive and large enough to bear such costs can start exporting (Melitz, 2003). Participation in GVCs does not require firms to penetrate foreign markets directly, but instead requires them to develop capabilities to meet the quality requirements and standards set by global buyers (Henson and Humphrey, 2010). In the empirical analysis described in the Box 2, higher productivity level and larger firm size are found to increase the chance that Latvian firms start exporting significantly (Box 3). 
Figure 14. Exporting firms are more productive, especially those participating in GVCs The share of exporters in the total number of Latvian firms, 2014
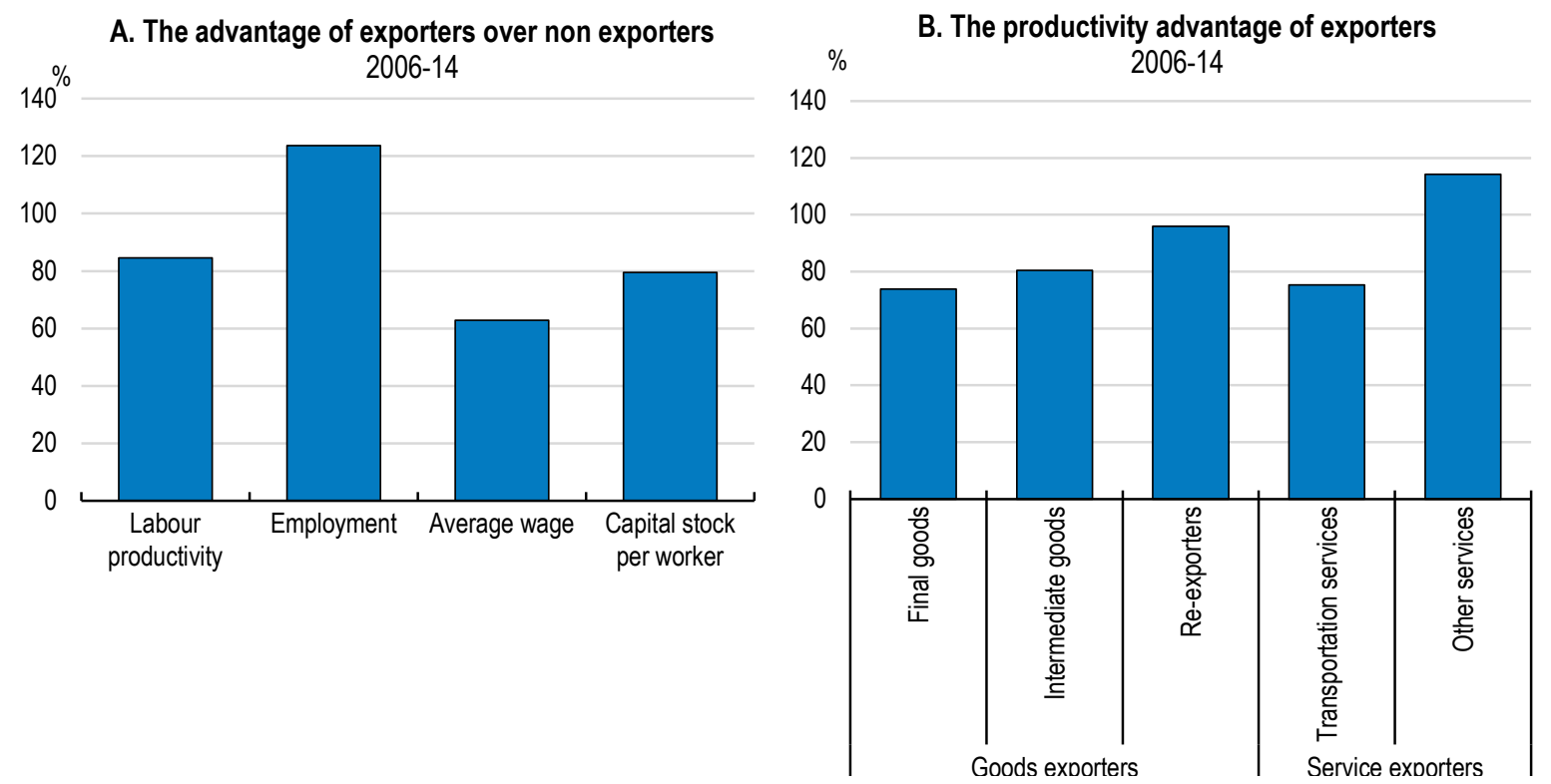

Note: This chart summarises the advantage of exporting firms over non-exporters. For example, the left-hand side bar in Panel A indicates that exporters are $84 \%$ more productive than non-exporters.

Source: Benkovskis et al., 2017, "Export and productivity in Global Value Chain: Evidences from Latvian and Estonian firms" OECD Economics Department Working Paper, forthcoming.

The large performance advantages of exporting firms are not driven by few very productive exporters but are broad-based. About $30 \%$ to $45 \%$ of non-exporting firms have a productivity level lower than the least productive exporters (Table 1). There are many non-exporters with very low productivity. The large productivity gap between exporting and non-exporting firms is a concern because many Latvian firms may have a productivity level that is too low to be competitive and to overcome the initial costs of participating in GVCs.

Table 1. Productivity is very low in many non-exporting firms

Share of non-exporting firms with lower labour productivity than the lowest decile of exporting firms, per cent

\begin{tabular}{l|cc}
\hline & Latvia & Estonia \\
\hline 2006 & 45.1 & 31.2 \\
\hline 2007 & 44.9 & 32.3 \\
\hline 2008 & 43.6 & 32.2 \\
\hline 2009 & 40.1 & 35.7 \\
2010 & 43.0 & 35.3 \\
\hline 2011 & 37.2 & 33.6 \\
\hline 2012 & 31.0 & 34.4 \\
2013 & 39.1 & 34.7 \\
2014 & 31.1 & 35.1 \\
\hline
\end{tabular}

Source: Benkovskis et al. (2017), "Export and productivity in Global Value Chain: Evidences from Latvian and Estonian firms" OECD Economics Department Working Paper, forthcoming. 


\section{Participation in GVCs increases productivity, employment and wages}

Even between firms with initially similar level of productivity, size and age, those that start exporting enjoy substantial productivity gains compared to those that did not enter export markets. Exporting enables firms to realise more than 23\% higher labour productivity in the year of export entry (Figure 15). The gain in productivity is largely maintained in subsequent years. The large gain in productivity in the year of export entry partly reflects the increase in capacity utilisation or scale economies. The gain in productivity would increase over time if export entry results in improvement in technological capabilities or innovation. This is the case for firms that start re-exporting or start to export services (Benkovskis et al., 2017). It suggests that those firms are translating knowledge acquired through GVC participation into stronger capabilities.

Export entry also increases employment, indicating that the higher labour productivity is not driven by labour shedding (Figure 15). Exporters also pay $8 \%$ higher average wages than non-exporters in the second year of export entry, perhaps because firms hire more high-skilled workers, or reduce wage underreporting. Entry to exports of intermediate goods and service exports result in particularly larger employment, while re-exports and export of non-transport services result in particularly higher wages (Beņkovskis et al., 2017).

Figure 15. Exporting raises productivity, employment and wages of Latvian firms

Differences in productivity, employment and wages between exporting and non-exporting firms after export entry

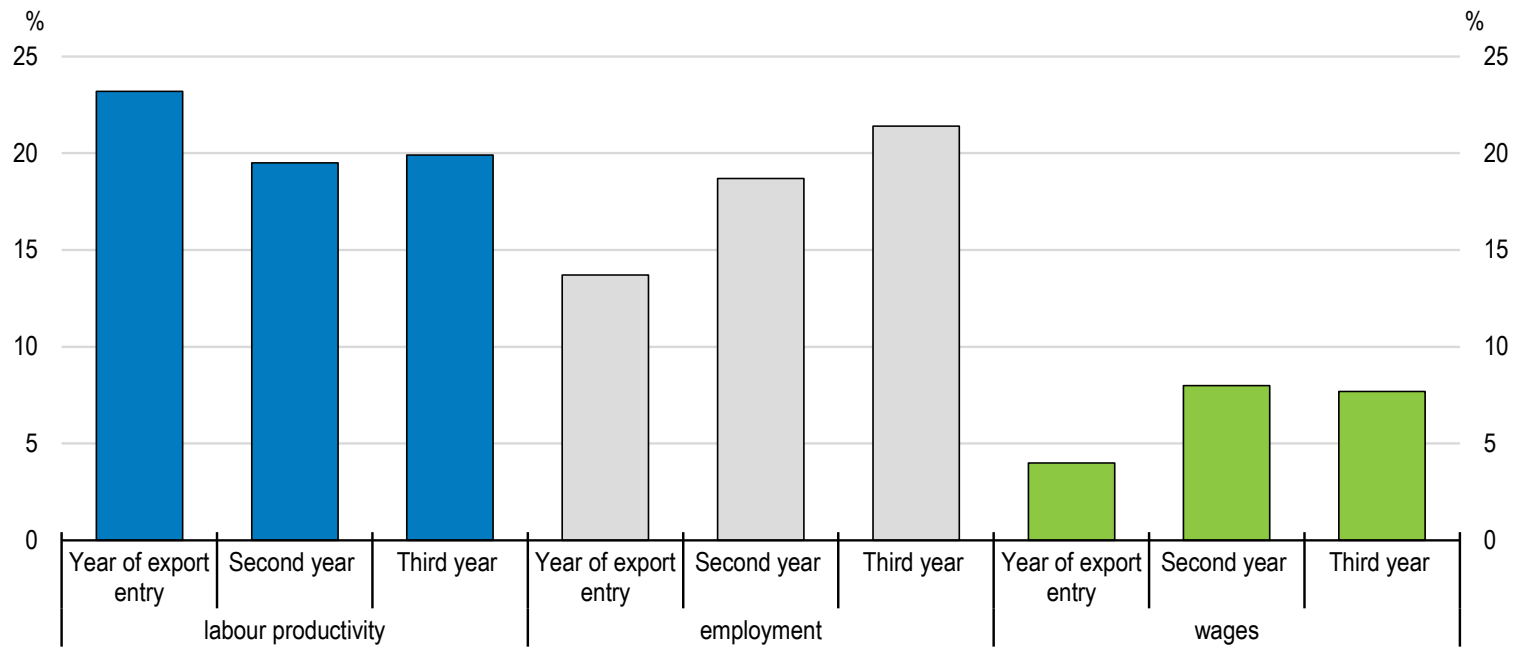

Note: The chart shows the differences in average productivity, employment and wages between firms that started exporting and nonexporting firms. By comparing the export entrants only with the subset of non-exporting firms that are initially as productive and large as the export entrants, differences in performance can be interpreted as causal effect of export entry. See Box1. 2 for details.

Source: Benkovskis et al. (2017), "Export and productivity in Global Value Chain: Evidences from Latvian and Estonian firms" OECD Economics Department Working Paper, forthcoming.

Participation in GVCs through exports boosts productivity and allows Latvian firms to increase better quality jobs, yet only the most productive firms are able to participate in GVCs. Further integration in GVCs may result in a wider productivity gap between a handful of exporters and the large mass of nonexporters, unless the number of firms participating in GVCs increases. A more inclusive participation in GVCs requires boosting the productivity of smaller non-exporting firms and ensuring that firms seeking to start exporting can access the resources needed to overcome barriers to enter export markets. Indeed, 
access to credits, skilled workers and knowledge about foreign markets are among the most important determinants of export entry of Latvian firms (see Box 3).

\section{Box 3. The determinants of participation in GVCs}

This Box reviews the main determinants of export entry by Latvian and Estonian firms, obtained from the estimation of the probability to start exporting described in the Box 1.2. The empirical findings are drawn from Benkovskis et al. (2017) unless otherwise cited.

1. Labour productivity: Higher productivity level increases the likelihood that Latvian and Estonian firms start exporting. For Latvian firms, the effect of higher productivity on export entry is larger for exports of final goods and for re-exports than for export of intermediate goods and services.

2. Firm size: Larger firms are significantly more likely to enter exports, even after incorporating the fact that more productive firms are larger. For Latvian firms, the effect of larger firm size on export entry is larger for export of final goods than for export of intermediate goods and services. The probability of export entry decreases after firms reach a certain size.

3. Firm age: Younger firms are more likely to start exporting in both Latvia and Estonia, although this is not true for very young firms.

4. Capital intensity: Latvian and Estonian firms with higher capital-labour ratio are more likely to start exporting

5. Access to credit: Firms with higher liquidity ratio is more likely to start exporting in Estonia, while this is the opposite in Latvia. One possible interpretation is that Latvian firms are subject to credit constraints and therefore need to use internal cash flow to finance the upfront costs of export entry.

6. Skilled workers: Hiring managers or employees who previously worked for MNEs or exporting firms increases significantly the probability of Estonian firms to start exporting (Masso et al., 2015; Masso and Vahter, 2016). Hiring of ex-employees of exporting firms also increases the likelihood of export entry by Latvian firms. This underscores the importance of skilled workers in GVC participation. It is also in line with the view that the mobility of skilled workers as a key channel of knowledge spillovers (Dasgupta 2012).

7. Foreign capital: For both Latvian and Estonian firms, firms with a higher foreign capital share are more likely to enter export markets. These firms can be participating in the supply chains operated by MNEs or enjoy transfer of knowledge in foreign markets.

\section{Policies that boost skills, innovation and resource allocation foster inclusive participation in GVCs}

\section{Improving access to higher education and lifelong upskilling opportunities}

Further participation in GVCs and moving up the value chain requires high-skilled workers. Skills are also pre-requisite for stronger innovation capabilities and competitiveness in knowledge-intensive activities. Stronger skills also increase the economy's capacity to benefit from knowledge spillovers associated with GVC participation. It would allow more Latvians to enjoy the employment opportunities created by further integration in GVCs. Latvia has made progress in raising skills. Today almost all Latvians are educated at least to upper secondary education. Survey evidence indicates that $11 \%$ of Latvian workers report being underskilled and $20 \%$ being overskilled. The share of workers reporting that their skills were below the level required for their job is among the highest in European OECD countries (Figure 16, Panel A). By contrast over-skilling is low in international comparison (Figure 16, Panel B). The shortage of workers equipped with adequate skills can hinder reaping greater benefits from participating in GVCs. 
Figure 16. The incidence of under-skilling is high while over-skilling is rare

$$
2014
$$

A. The share of employees reporting lower skill level than required for their current jobs

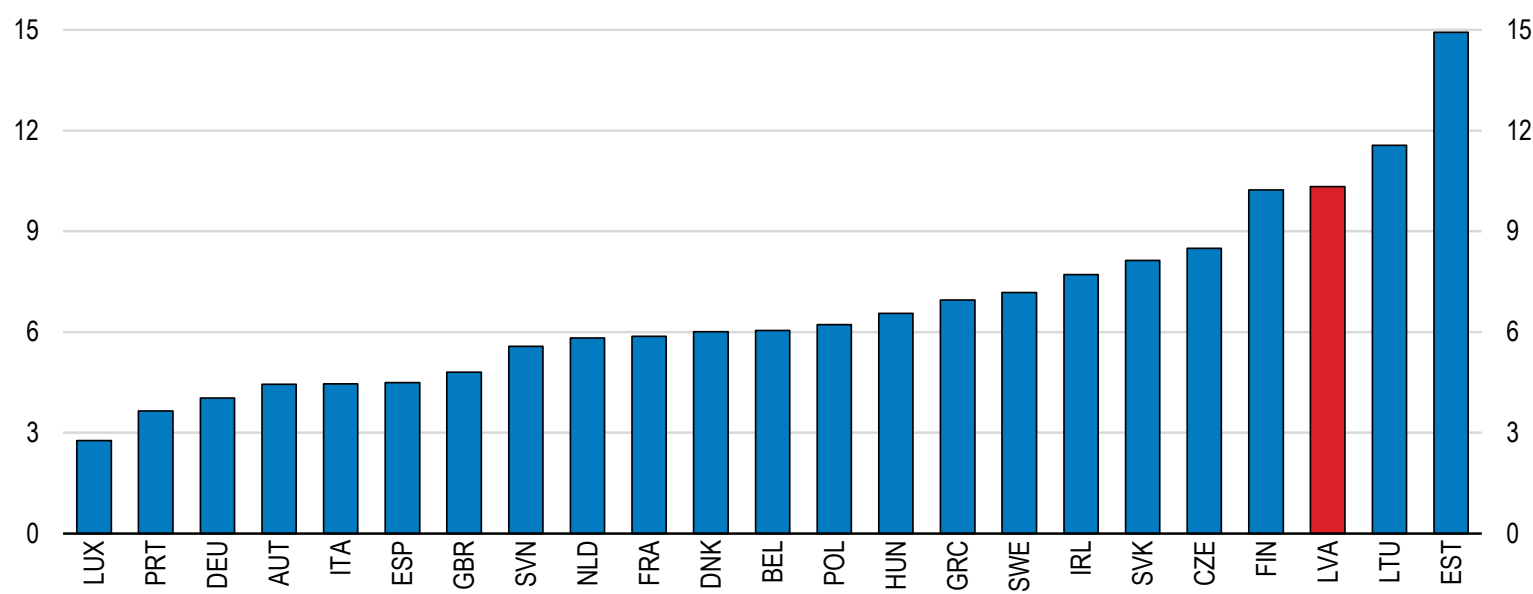

\section{B. The share of employees reporting higher skill level than required for their current jobs}

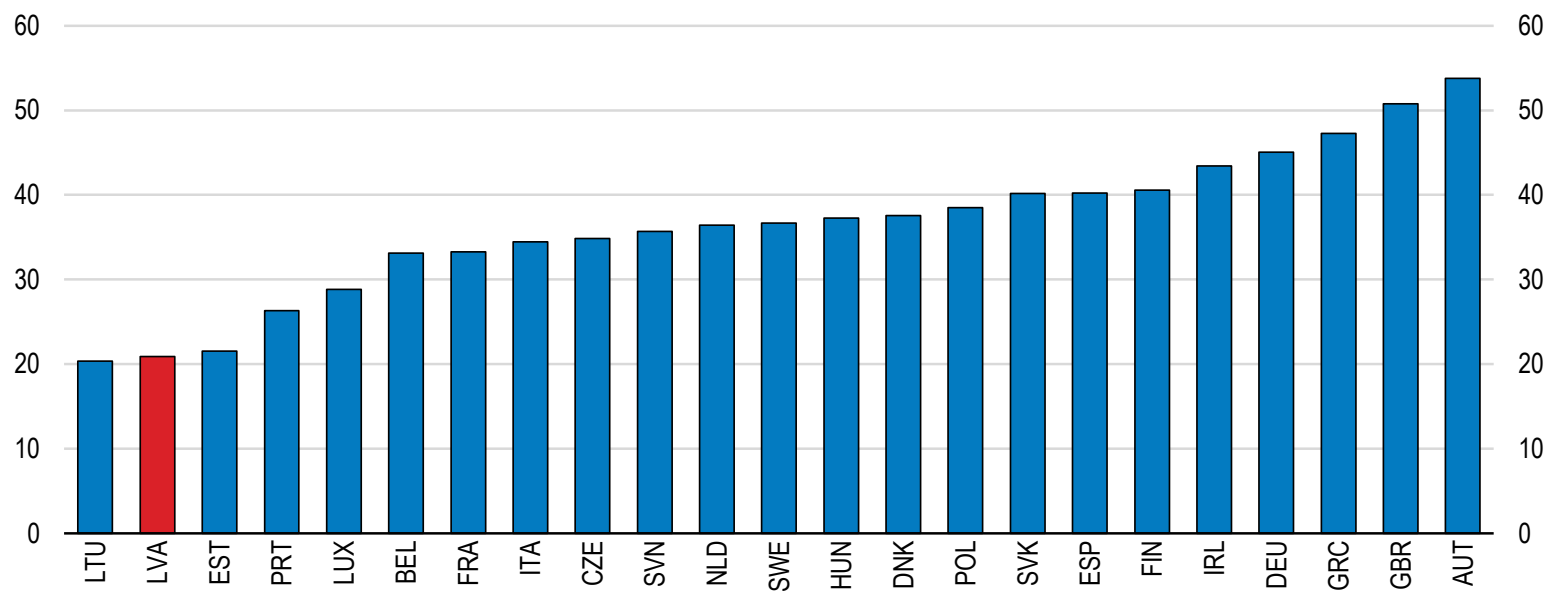

Source: CEDEFOP (2016), "Skills Panorama" (http://skillspanorama.cedefop.europa.eu).

\section{Expanding access to high-quality vocational education and training}

Latvia has made substantial progress in improving the quality of vocational education and training (VET). Comprehensive VET reform has improved the quality and labour market relevance of training programmes through stronger involvement of social partners. Modularised education programmes were developed, enabling more systematic acquisition of specific skills and introducing up-to-date teaching methods (OECD, 2016a). VET schools have been consolidated and multi-functional VET Competence Centres (VECCs) were established. They experiment with new programs and also offer adult training. A workbased learning model was implemented in 2016 and a legal framework regulating the employment relationships between the student, firm and school during the workplace learning has been established.

The government aims to equalise participation rates in upper secondary general education and VET by 2020. Further acceleration in the development of modular programmes, professional qualification exams and occupational standards will contribute to meeting this ambitious objective. While the expansion of 
work-based learning is important in narrowing the gap between skills acquired in VET and those demanded in the labour market, it is held back by the limited number of firms offering training places. The government could consider introducing incentives in order to encourage smaller, resource constrained firms to offer workplace training. Given that the productivity of students is lower than that of regular workers, the government may also consider introducing an exemption to the minimum wage for workplace learning.

A wider access of students who are likely to come from low- and middle-income families to the upgraded VET programs would address the shortage of medium to high-skilled workers, contributing to productivity growth and inclusiveness. However, the access of students from disadvantaged socio-economic background to VET is held back by low income support. In periods in which VET students are on workplace-placed training, they may receive a stipend from their employers. The stipend benefits from a tax-exemption (up to a ceiling). Nevertheless, most students only receive 40-70 euros per month of meanstested income support, which is not sufficient to cover their living expenses (Baranovska, et al., 2015). As a result, there is a concern that students from low income households are forced to combine studies and work, often leading to declining academic achievements and attendance, which in turn lowers their eligibility for continued support (Baranovska et al., 2015). Furthermore, students receiving support are no longer qualified for the family allowance, which amounts to between 11 and 50 euros per month, creating a potential disincentive for poor families to send their children to VET. According to the data from the Central Statistical Bureau, in the academic year 2014/15, about 17\% of VET students dropped out of programs. The most frequent reasons for dropping out were family reasons followed by non-attendance. The mean-tested scholarship should be increased to a level that allows students to concentrate on completing VET programs and be made compatible with state family benefits. The government envisages additional support for students at risk of early school leaving, funded by EU structural funds, which is welcome.

\section{Making the most of ongoing improvements in higher education}

The quality of tertiary education has been enhanced through establishment of internal and external quality assurance system that conforms to the standards of the European Union. A new funding system allocates resources according to the results of these assessments, the alignment of university programs with labour market demand, and innovation activities by tertiary education institutes (OECD 2016a). The quality assessments will incorporate indicators of labour market performance of graduates from individual universities in the near future. In response to the strong labour market demand for graduates in Science, Technology, Engineering and Mathematics (STEM), the government has allocated more state-funded free study places to these subjects.

These reforms should increase the supply of high skilled workers with relevant skills, if coupled with measures to increase the access to tertiary education. However, low financial assistance is hindering the access of students from disadvantaged socio-economic backgrounds. The scholarship is mainly meritbased and is not available for all students eligible for free study places. Furthermore, its amount is not sufficiently high to cover living costs. Household income only plays a role when merit is the same. Some universities also offer their own grants for students from low-income families. Student loans are available but their repayment is not income-contingent. These conditions are especially challenging for low income students living in rural areas who want to pursue STEM studies, because they need to bear the living expenses in the, sometimes distant, towns where STEM studies are offered. The merit-based system should be modified to include means-tested income support to improve access of talented students from disadvantaged socio-economic backgrounds to higher education. 


\section{Promoting adult learning and education is important especially among low skilled workers}

Participation in GVCs exposes Latvian firms and workers to new technologies and organisational practices, which make some skills obsolete. Latvian workers need opportunities to update their skills in order to benefit from stronger integration to GVCs. The government has set an ambitious target to have $15 \%$ of the adult population actively involved in education and training by 2020 (MoES, 2014). Still in $2016,7.3 \%$ of 25-64 year-olds participated in formal or non-formal education and training, a share that is considerably lower than other European countries (Figure 17). In order to address the weak participation, an action plan that establishes a governance framework and quality control of adult education was approved in 2016, which is welcome. The action plan is currently financed mainly by EU funds and the central government is foreseen to start financing adult education from 2022 onwards.

Figure 17. Participation in lifelong learning is low

Participation rate in lifelong education or training, 25-64 year-olds, 2016

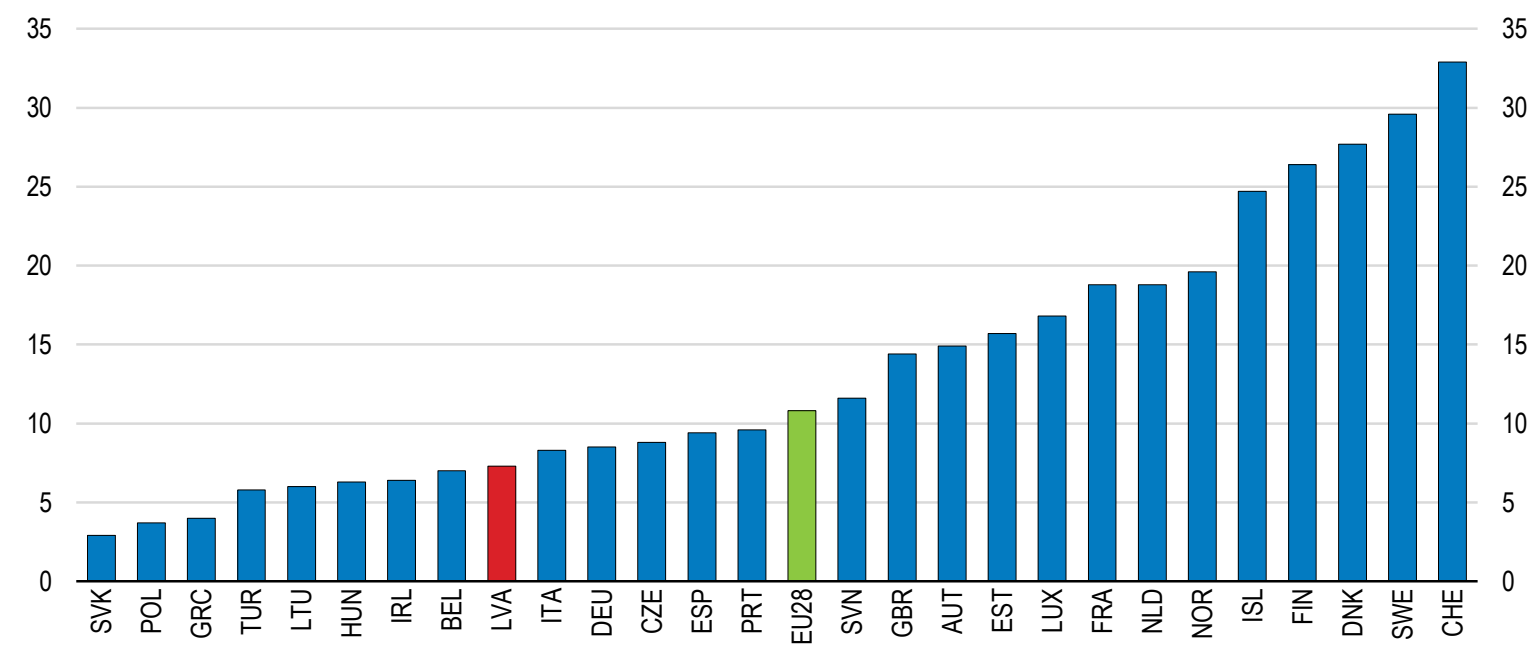

Note: Data refer to the share of 25 to 64 year-olds who participated in education or training in the 4 weeks prior to the survey.

Source: Eurostat (2017), Education and training statistics (database).

The provision of adult education can be boosted by making better use of VET schools that recently underwent considerable reform. Currently, among VET schools, only some (the VET Competence Centres, VECCs) offer adult education partly due to state budget rules that limit the possibilities for public VET schools to retain additional income gained through offering of adult education (OECD, 2016a). Such disincentive should be removed. The action plan mentioned above includes measures to strengthen the capacity of VET schools to offer adult education. More could be done by introducing legal requirement and incentives for VET schools to offer adult education, as done for VECCs.

Encouraging participation in adult education is especially important among low educated workers. Low educated workers in Latvia faces particularly large skill gap in their jobs (Figure 18). Still, less than 11\% of Latvian adults with a lower secondary education or less participate in adult education and training, a rate that is about five times lower than for those with tertiary education (OECD, 2016a). Measures to encourage participation by low skilled workers should be strengthened. This would broaden access to employment opportunities created by firms' GVC participation. 
Figure 18. Low educated employees face particularly large skills gaps $\%$ of workers reporting foundation, transversal, job-specific skills gaps by educational level ${ }^{1}, 2014$

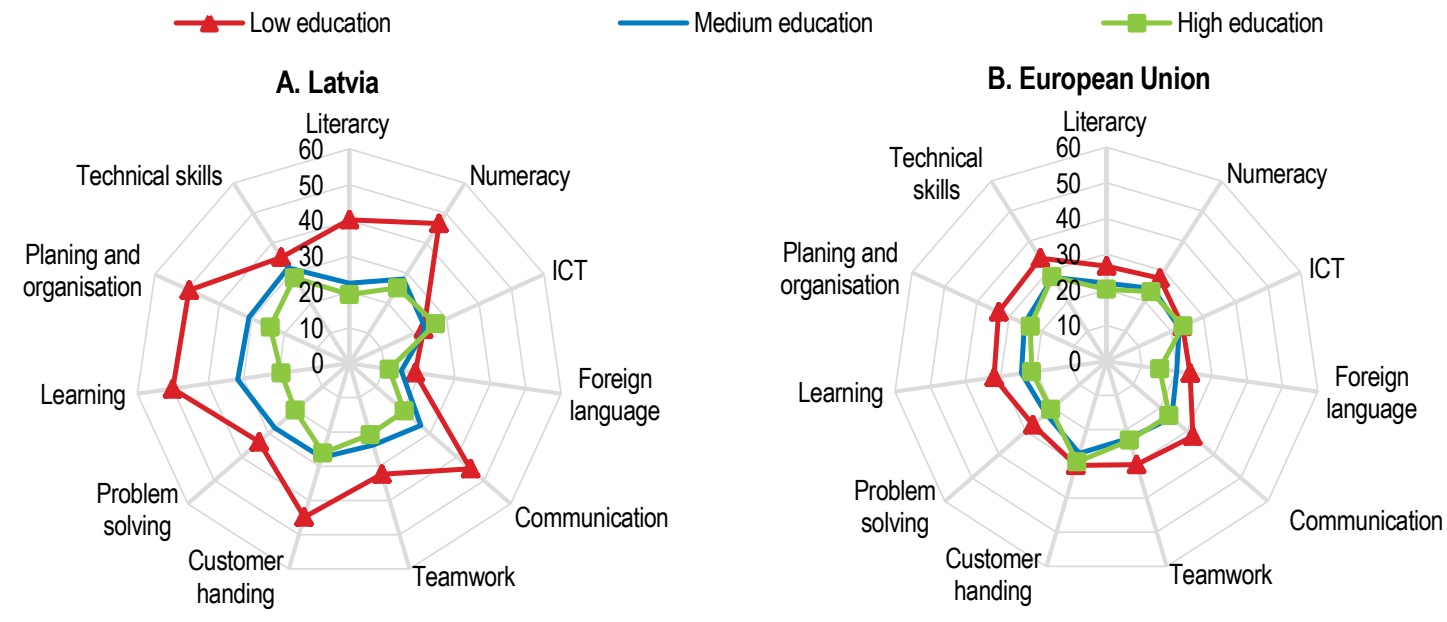

1. The percentage of employees whose foundation (literacy; numeracy; ICT; and foreign languages), transversal (communication; customer handling; learning; planning and organization; problem solving; and team-working), job-specific skills are ranked lower/are barely matched to the level needed to do their job. Respondents were asked to score, on a $0-10$ scale on skills compared to what is required for doing their job, where 0 means their level of skill is a lot lower than required and 10 means their level of skill is a lot higher than required. Scores below 7 (the lowest quartile) were used to calculate all skills gaps except foreign language skills gaps. Scores below 5 (the lowest quartile) were used to calculate foreign language skills gaps. Both country data and the aggregated data for EU28 are weighted by occupation, industry, education, age and gender by using a given weight in the database.

Source: OECD calculations based on the European skills and jobs survey (2014), Centre européen pour le développement de la formation professionnelle (Cedefop).

\section{Promoting the participation of women in high skill jobs}

Policies to remove barriers for women to access good job careers can also improve the supply of skills. The gender wage gap is particularly large for well-paid positions, pointing to poor utilisation of highly skilled female employment, and can for the most part not be explained by job or personal characteristics (Gaveika and Skrūzkalne, 2012). Shortages in the supply of formal early child care hold back the reconciliation of employment and family life (European Parliament, 2015). Steps to encourage women to study science, technology, engineering or mathematics (STEM), where free study places are abundant and labour market demand is strong, would reduce skill shortages and the gender gap in earnings (OECD, 2016a). Barriers to female entrepreneurship could also be identified and addressed. Another option, suggested by Turk et al (2010), is to require firms to identify and address pay inequalities between men and women. Germany has recently taken steps in this direction.

\section{Migration policy should target foreign skilled workers}

Latvia needs to attract talent and skills from abroad to address skills shortages. The possibility of hiring talented individuals from abroad can facilitate the participation of Latvian firms to GVCs. Indeed research has shown that hiring of employees who have worked in MNEs boosts GVC participation (Box 3). Yet, Latvia is not very successful in attracting high skilled foreign workers. The share of foreign-born workingage individuals in Latvia with a degree from tertiary education is lower than in other Baltic countries (Figure 19). It is also slightly lower than the share of native Latvian workers completing tertiary education, 
which contrasts with countries with immigration policies geared toward attracting highly-skilled individuals.

Figure 19. Latvia is not attracting highly educated immigrants

Share of the highly educated among native- and foreign-born 15-64 year-olds ${ }^{1}, 2013$ or latest year

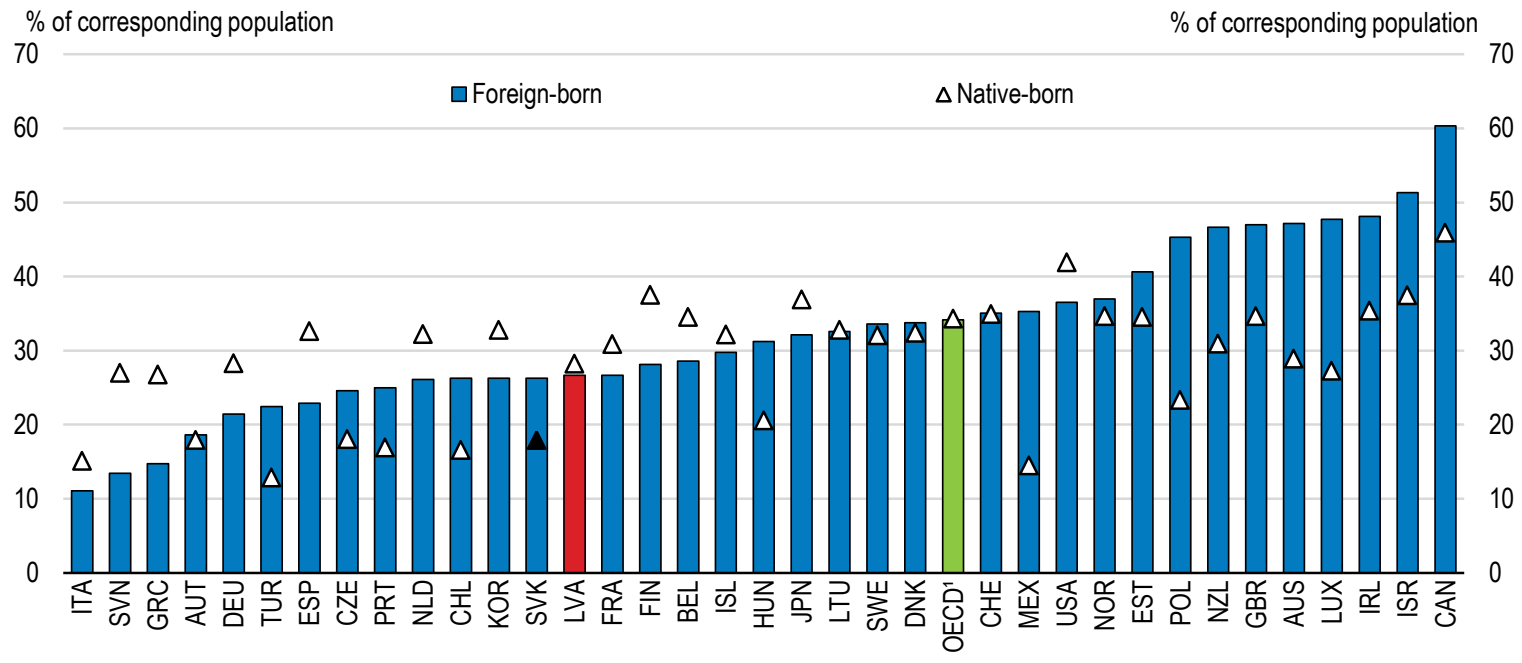

Note: Highly educated people with tertiary education attainment at the levels 5 and 6 (ISCED-97).

1. Latvia was excluded because Latvia was not yet a member of the OECD at the moment of publication.

Source: OECD (2015), OECD Science, Technology and Industry Scoreboard 2015: Innovation for growth and society.

Apart from return migration, the immigration flow to Latvia is low (OECD, 2016b). Latvia's work permit framework is aligned with EU legislation. However, unlike Estonia, Latvia does not provide any preferential treatments to skilled immigrants from non-EU countries in obtaining residence permits (OECD, 2016b). Furthermore, these foreign workers are not covered by the public health insurance scheme and must purchase private health insurance at an additional cost. There is also a requirement of Latvian language proficiency for many occupations that requires communications with the public or government authorities, which limits the scope of jobs that foreign skilled workers can take up.

International students represent another potential pool of talent and skills. While their number has increased rapidly, reaching 5\% of enrolled students in higher education in 2014, only a handful of them stay after their graduation. The government has set a goal of increasing the share of graduated international students staying in Latvia to $10 \%$ by 2030 . A national agency has set up a website to promote Latvia as a study destination. Students from outside the EU who finish their studies in Latvia are entitled to request up to six months of residential permit for job searching. However, there are no arrangements to facilitate their hiring, such as fast-track acquisition of working visas or easing of labour market tests.

\section{Boosting knowledge transfer and innovation capabilities of Latvian firms}

Innovation boosts productivity and creates new businesses and jobs through new products, technologies and managerial methods (OECD, 2015a). Latvia's competitiveness in more knowledge-intensive, high value added activities within GVCs depends on developing an efficient innovation system that facilitates knowledge transfer and stimulates commercialisation of new technologies and investment in knowledgebased capital. 


\section{Business-based innovation is weak}

Latvia's investment in research and development $(R \& D)$ is among the lowest in the OECD (Figure 20). It is primarily driven by public research institutions. Less than one-third of $R \& D$ expenditure is businessbased. In 2014, 24\% of business-based R\&D was funded by EU structural funds. The share of Latvian firms engaged in innovation such as the introduction of new products, processes, marketing or organisational structures is among the lowest in the EU countries (Figure 21). Only few firms are introducing new products that they consider new to the market (Figure 21). Innovation by Latvian firms are characterised as adoption of recent technologies rather than frontier innovation, largely reflecting the ongoing catch-up process. $78 \%$ of the innovation expenditure by Latvian firms was used to purchase of technologically advanced equipment and software (CBS, 2016). However, several indicators of innovation performance such as the number of non-EU doctoral students in Latvia have improved most recently, allowing Latvia to exit the group of least performing EU countries (European Commission, 2016a).

Figure 20. Research and development expenditure is among the lowest in the OECD

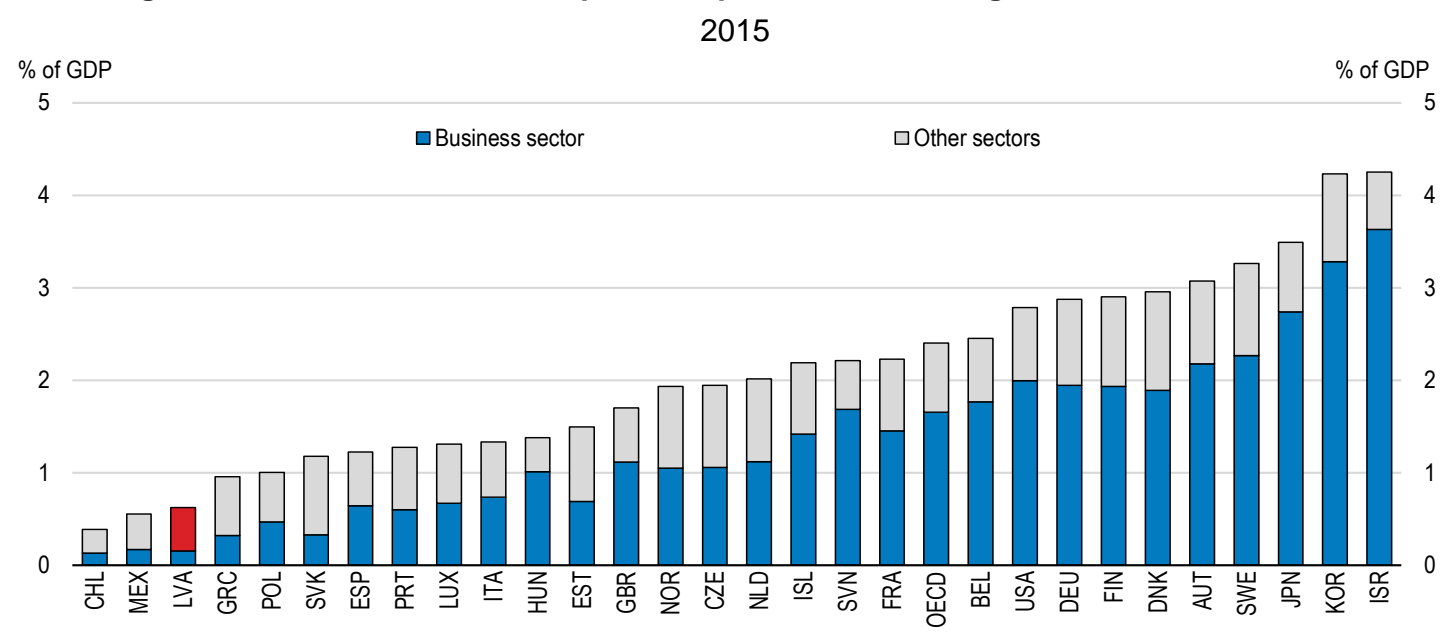

Source: OECD (2016), OECD Main Science and Technology Indicators (database).

Figure 21. Business-driven innovation is low

The share of innovating firms in all firms surveyed, 2012-14

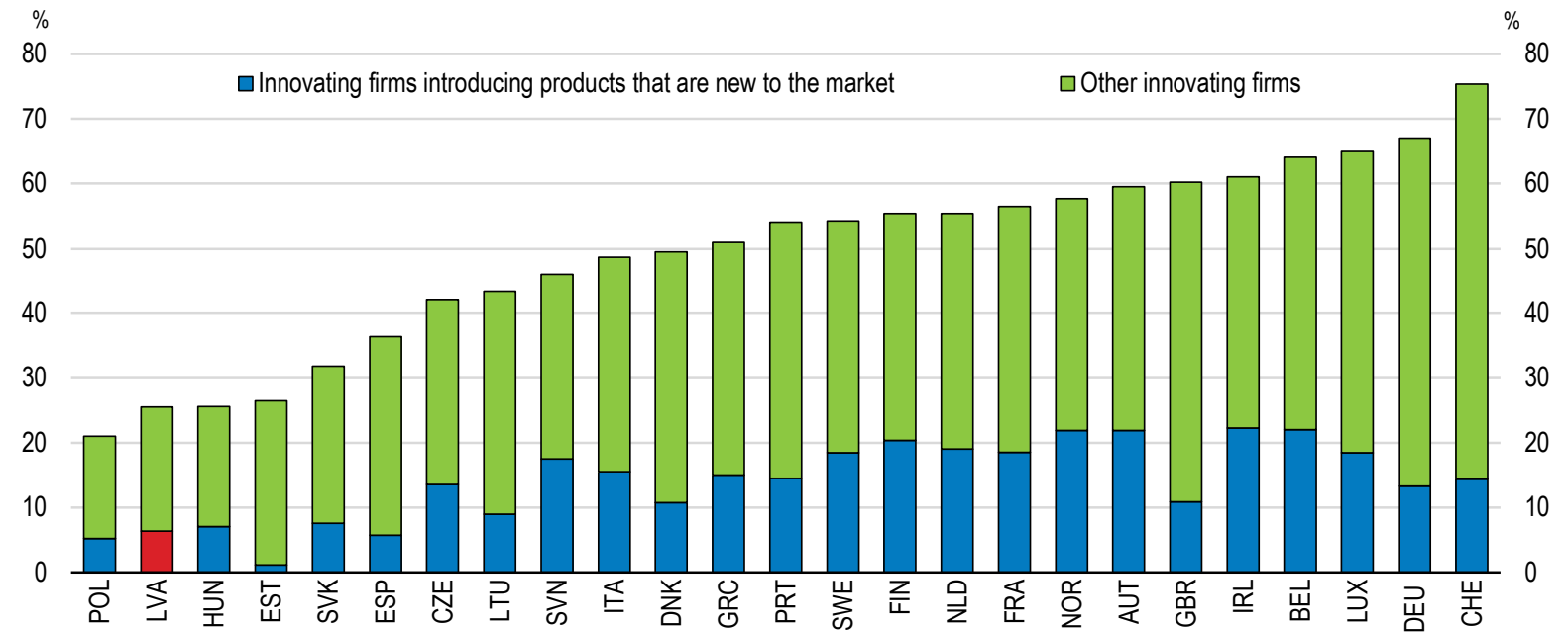

Note: International comparability may be limited due to differences in innovation survey methodologies and country-specific response patterns.

Source: Eurostat (2016), Community Innovation Survey (CIS) 2014. 


\section{Stronger cooperation would boost innovation}

The low innovation performance of Latvian firms goes hand in hand with their low engagement in innovation cooperation. Cooperation is especially effective in saving costs of innovation under rapid pace of technology changes and increased complexity of innovation activities. It includes co-developing innovations with other companies, procuring research services such as $R \& D$ or design, licensing the rights to others' inventions or simply imitating innovations developed and adopted elsewhere. Only one-fourth of innovating Latvian firms engaged in cooperation during 2012-2014 (CSB, 2016). Cooperation occurred predominantly between suppliers of equipment and inputs with other firms. Such cooperation, especially with multinational enterprises (MNEs) is often a promising channel of knowledge transfer and productivity growth (Hoekman and Javorcik, 2006).

Cooperation between higher education or research institutions is a promising avenue for boosting the innovation capabilities of Latvian firms. However, the share of innovating firms that collaborated with higher education and research institutions is lower in Latvia than most European countries (Figure 22). The weak link with research institutions has been found to constrain the ability of Latvian firms to innovate and to identify and absorb new technologies developed outside the country (Jesilevsca, 2016). Enhancing cooperation especially among young firms that are more eager to experiment with new technologies can accelerate the commercialisation of frontier technologies and strengthen Latvia's ability to move up the value chain.

Figure 22. Cooperation with higher education or research institutions in innovation is low

The share of firms cooperating in all product and/or process-innovating firms, 2012-14

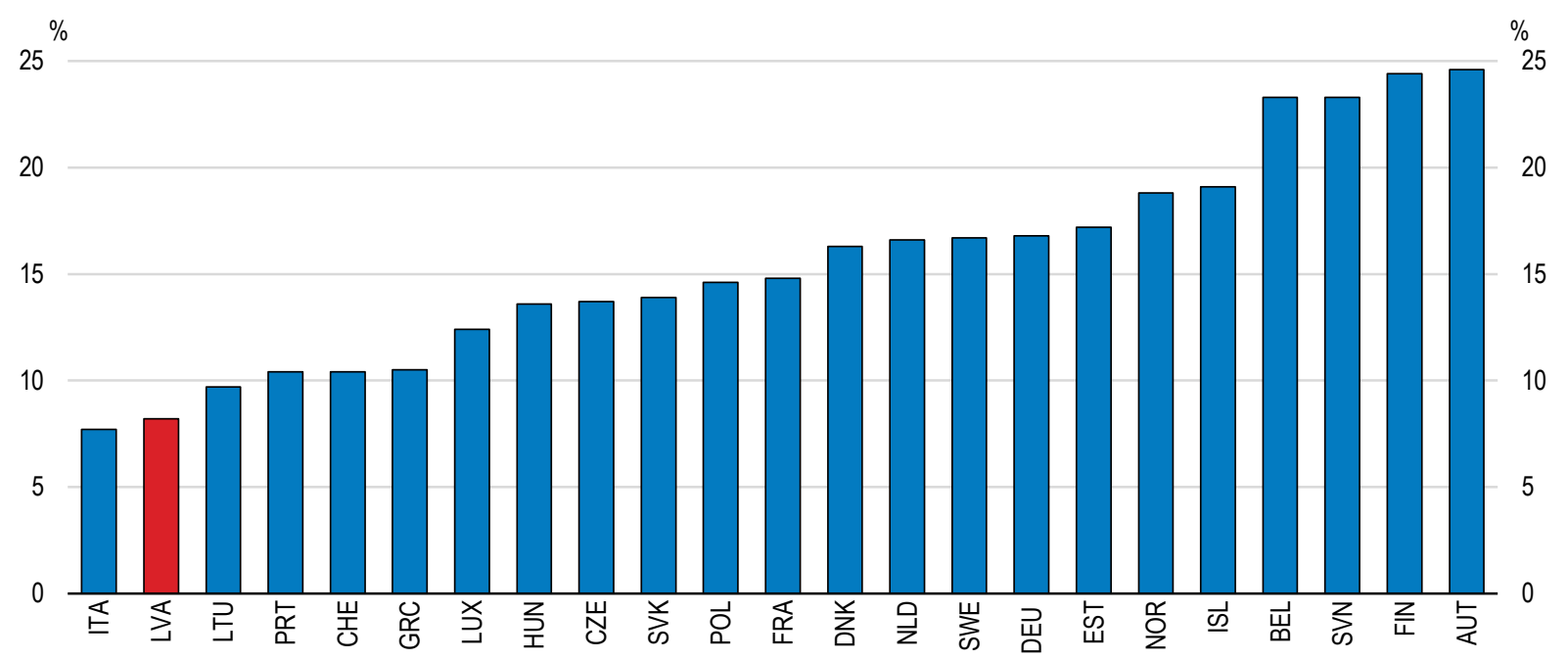

Note: International comparability may be limited due to differences in innovation survey methodologies and country-specific response patterns.

Source: Eurostat (2016), Community Innovation Survey (CIS) 2014.

Latvia has taken several policy initiatives in order to boost innovation and cooperation, especially in areas defined in the Smart Specialization Strategy. It includes the EU-funded Competence Centre support programme which aims to raise the competitiveness of Latvian firms by fostering cooperation between research institutions in developing new products, as well as the EU-funded Applied Research Grants programme, the Post-doctoral Research Grants programme and the support programme for the Modernization of Higher Education and Research Infrastructure. Other measures such as the Cluster programmes and the Innovation Voucher scheme help firms, including SMEs, to access knowledge in 
research institutions and encourage local and international knowledge transfer. Steps have also been taken to stimulate mobility of workers between the business sector and the public sector. Many of these policies have been implemented only recently or are in the process of implementation. Reform of higher education funding introduced in 2015 also provides incentives for universities to cooperate with businesses, which is welcome.

Considering the small size of domestic research capabilities and the large scope for technology catch-up, cooperation with foreign research institutions is particularly important for strengthening productivity in Latvia. Many of the policy measures mentioned above extend to international collaboration in principle. For example, the Competence Centers scheme can be applied to R\&D services provided by foreign research institutions if those services are not available in domestic institutions. The Cluster Program envisages promoting the international cluster-to-cluster cooperation in research and innovation activities. Measures to strengthen the international co-operation between researchers were also put in place. However, those measures have not so far resulted in a notable increase in international research collaboration. Latvian firms favour collaboration with domestic institutions due to higher research costs abroad.

The funding allocated to innovation policy, mostly from EU funds, is thinly dispersed across numerous support measures to basic research, commercialisation of research and development and research cooperation. There is a risk that those policy measures might not reach the critical mass to be effective. It is therefore important that the measures are rigorously assessed for their effectiveness and fiscal resource is swiftly reallocated accordingly. The evaluation of innovation support measures consists of ex-ante, midterm and ex-post evaluation. Amendments and corrections, even eliminations of some measures are possible, depending on the mid-term evaluation. The government must ensure that evaluation is strictly applied. From the perspective of promoting an inclusive participation of Latvian firms to GVCs, it is important to assess to what extent support measures helped the less productive, smaller firms that are overrepresented among non-exporters to boost their productivity. From the perspective of moving up the global value chains, the effectiveness of measures in promoting international cooperation should be evaluated.

\section{Improving resource allocation by enhancing the efficiency of the judiciary}

Public institutions that ensure contract enforcement and secure property rights are essential to support Latvia's GVC participation by allowing MNEs to more easily outsource complex tasks to Latvian firms. Latvian firms can also boost their productivity through outsourcing by specialising in the most competitive and profitable activities. Countries with efficient judiciary systems are found to be particularly more competitive in industries that rely on a wide range of intermediate inputs and in the production of higher value-added goods within an industry (Levchenko, 2007; Essaji and Fujiwara, 2012). More generally, stronger rule of law boosts economic growth by encouraging innovation and increasing the effectiveness of other policies enhancing competition and resource allocation (Guillemette et al., 2017).

Latvia has been engaging in reforming the judicial map and consolidating small municipal courts in order to increase efficiency. The average length of court proceedings has gradually decreased. The gradual consolidation of district courts is to be completed in 2018. Also, efforts to improve the quality of judgements are in the pipeline. The government envisages specialisation of some judges in the consolidated larger courts on specific topics such as insolvency or intellectual property protection. An action plan supported by the European Social Fund will be providing training to 12000 judicial sector workers until 2022, boosting capabilities in managing judicial processes and professional knowledge.

Increased out-of-court settlements such as arbitration or mediation would alleviate the burden of courts. Amendments to the Arbitration Law came into force in 2016, strengthening the state control on the arbitration courts. Sworn notaries and bailiffs were allowed to practice as certified meditator in the end- 
2015. Despite those measures, the use of out-of-court settlements remains rare. Further efforts to establish transparent framework of out-of-courts settlements are warranted.

\section{Increasing the transparency of the insolvency regime}

A transparent and efficient insolvency regime facilitates lending to investment needed to participate in GVCs and to engage in a more high value added activities (Manova and Yu, 2016). Effective insolvency also encourages firm creation and makes it easier to close unproductive firms, thereby enhancing the reallocation of important resources for GVC participation, such as skilled workers (Andrews and Adalet McGowan, 2016). While Latvia does not have many unviable firms remaining in business, as banks wrote off loans to non-viable firms quickly following the economic and financial crisis, there are concerns about transparency and abuse in insolvency cases (FCIL, 2016).

While the average costs and length of insolvency procedures in Latvia are close to the OECD average, the debt recovery rate is low (Figure 23). This is holding back lending to smaller firms and young firms with limited credit records (Bank of Latvia, 2016). The low recovery rate is mainly due to abuse with low penalty for abusers and low accountability of insolvency administrators. In order to strengthen the credibility of the insolvency regime, the government has adopted the Insolvency Policy Development Guideline which is being implemented between 2016 and 2020. Among others, these measures include more vigorous requirements for qualification and selection of insolvency administrators. From 2016, all administrators face the same obligations of income and assets disclosure as public officials. The amendment to the insolvency law in January 2017 strengthened the supervisory functions of the public insolvency administration. Capacity to prevent the abuse of insolvency regime is being built through the training program mentioned above. Coordination with the insolvency administration and the police has been strengthened. The specialisation of judges on insolvency is also likely to contribute to capacity building.

\section{Figure 23. The recovery of debt from insolvent firms is low}

\section{Average recovery rate, June 2016}

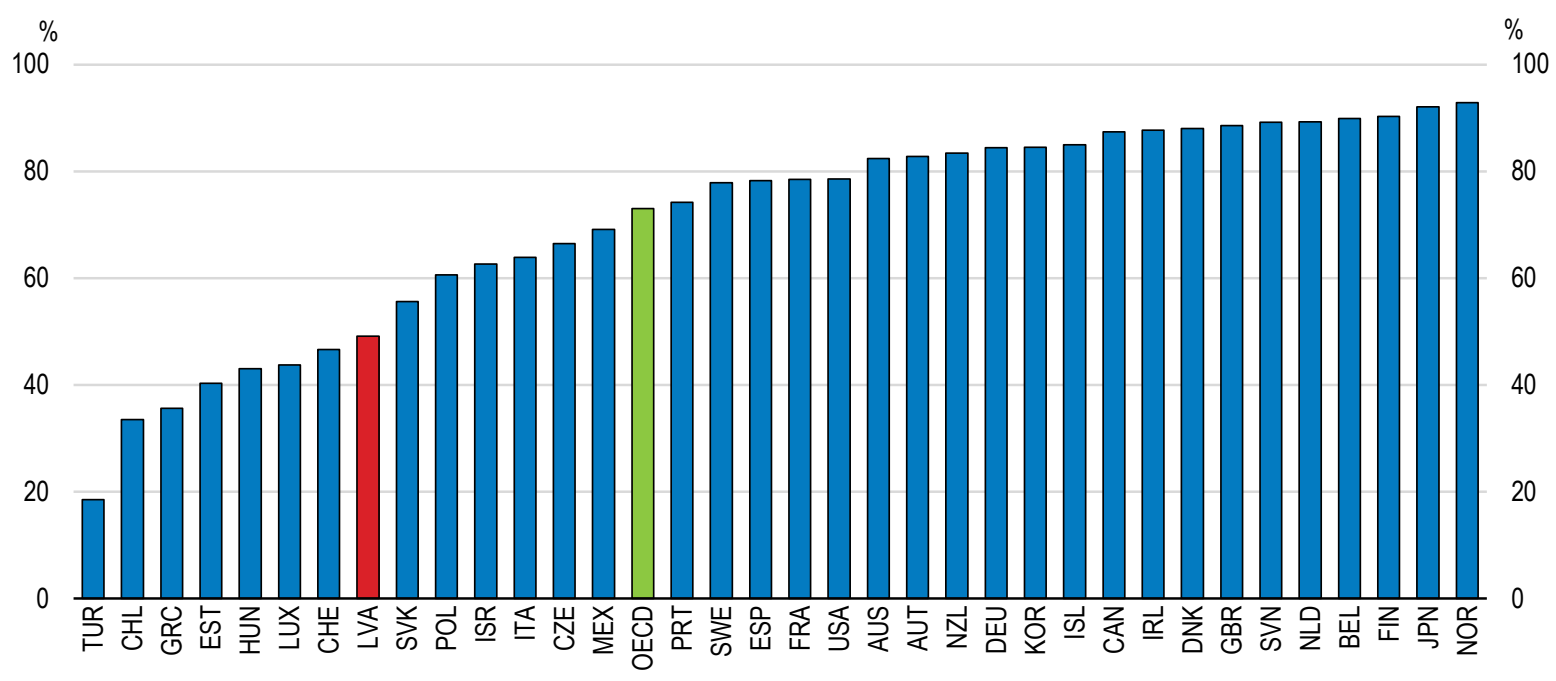

Note: The recovery rate is calculated based on the time, cost and outcomes of insolvency proceedings and is recorded as cents on the dollar recovered by secured creditors. The calculation takes into account whether the business emerges from the proceedings as a going concern or the assets are sold piecemeal. The costs of the proceedings are deducted. The value lost as a result of the time the money remains tied up in insolvency proceedings is also deducted. The recovery rate is the present value of the remaining proceeds.

Source: World Bank (2017), Doing Business 2016: Measuring Regulatory Quality and Efficiency (Resolving insolvency database). 


\section{Reducing informality through better governance}

While it is difficult to capture the exact size of informal economy, it is estimated to be between 20 to $25 \%$ of GDP in Latvia (Schenider, 2015, Putnins and Sauka, 2016). Around 20\% of business income and 10\% of wage payment are estimated to be undeclared, considerably higher than in Estonia or Lithuania (Figure 24). The large share of informal business activities undermines productivity growth by distorting the competitive advantage and resource allocation toward firms that do not comply with regulations and avoid tax (Hsieh, 2015). Such unfair competition condition is discouraging Latvian firms to grow in size and invest in innovation (European Commission, 2016b), which in turn holds back their participation in knowledge-intensive activities within GVCs. A recent survey among foreign-owned enterprises indicates that the prevailing informal economy is an obstacle to their further investment and expansion in Latvia (FICIL, 2016).

Figure 24. The size of the informal economy is large

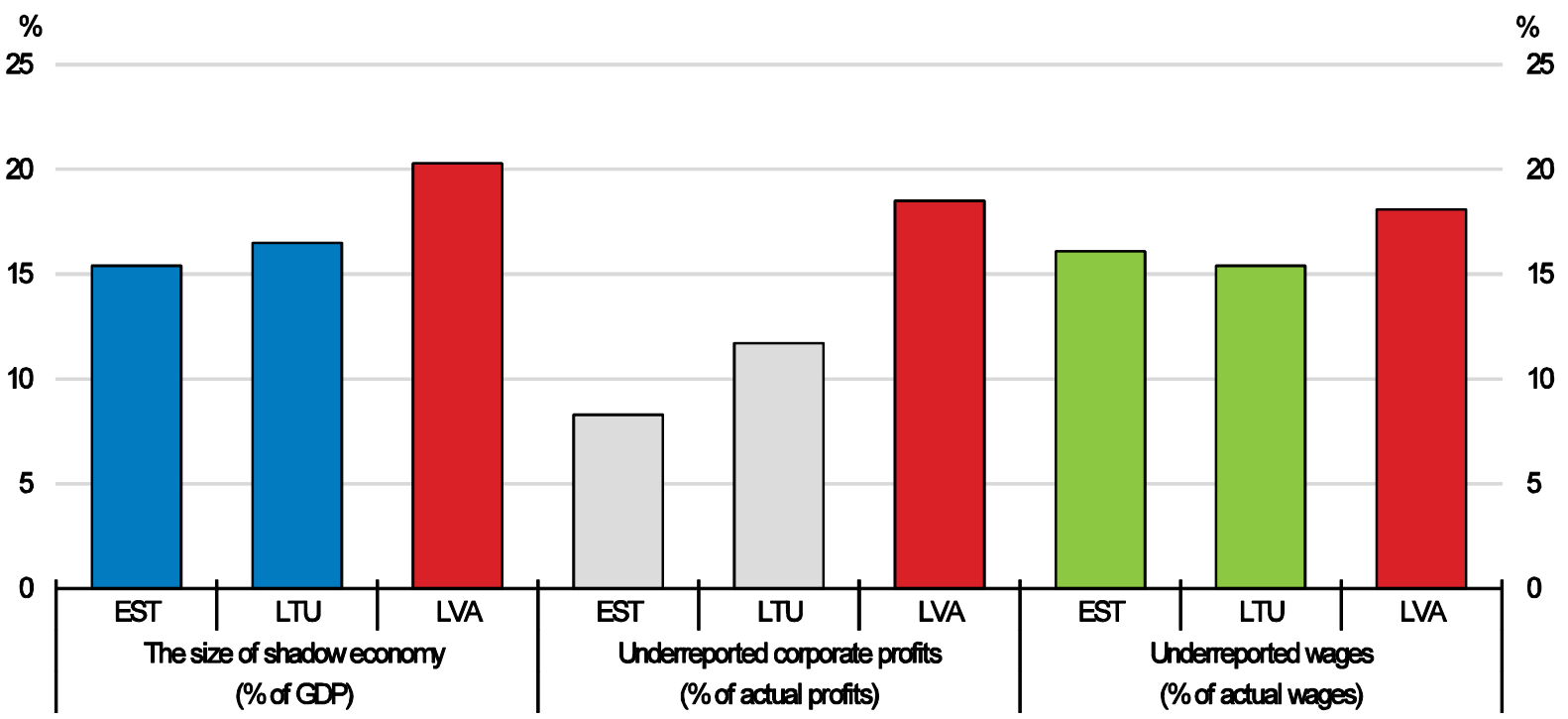

Note: The aggregate size of the informal economy is estimated from firm-level information. Underreported corporate profits and wage payments by registered firms in the three Baltic countries are based on survey data.

Source: Putninšs, T. and A. Sauka (2017), "Shadow Economy Index for the Baltic Countries", Stockholm School of Economics in Riga (SSE Riga).

The government has made considerable efforts to reduce the informal activities and to improve tax collection. It has intensified tax audits on individuals and firms operating in sectors where informal activity is widespread. It has introduced criminal sanctions against employers paying undeclared wages. It has strengthened controls, resources and coordination among relevant authorities (tax authorities, labour inspectors and customs), raised fines and increased personal liability of company board members. The government is also planning to make better use of ICT for tax law enforcement. It plans to require electronic record keeping cash registers. The government also plans to combat tax evasion in electronic commerce and to enable electronic exchange of information between credit institutions and the taxauthorities. This could be extended by requiring mandatory electronic invoicing and automated reporting in business to business transactions.

While those efforts are welcome, more fundamental efforts to reduce informal economy are needed. Studies have suggested that public's perceptions of weak governance undermine the willingness to pay tax. 
Surveys of company owners and managers shows that acceptance of informal activity is strongly related to their dissatisfaction with business legislation (Putnins and Sauka, 2016). In comparison with Estonia and Lithuania more Latvian businesses display lower trust in the government (Putnins and Sauka, 2016). Trust in public governance is also weak in the population at large (Figure 24). Greater trust in government helps improve tax morale (Daude et al, 2012). Better governance improves willingness to pay tax (Torgler and Schneider, 2007). Developing greater procedural justice, strengthening perceptions of impartial treatment of all citizens as well as ensuring broad and fair access to public services would improve trust to the government.

\section{Figure 25. Trust in the government is low}

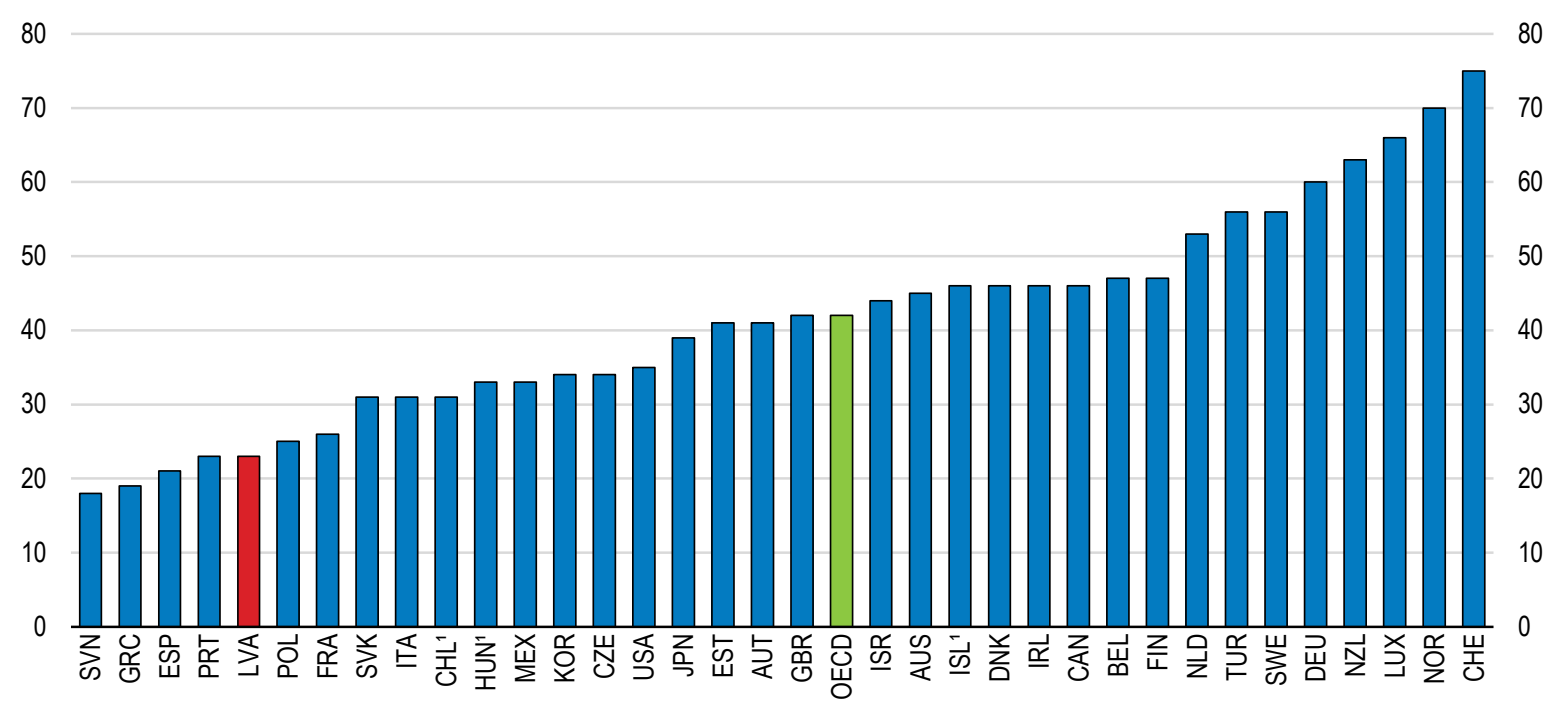

Note: Trust refers to the percentage of respondents who answered "yes" to the question "Do you have confidence in national government" in the World Gallup Poll, 2014.

1. 2013 for Chile, Hungary and Iceland.

Source: OECD (2015), Government at a Glance 2015.

Reforms to improve public sector efficiency have included more steps to fight corruption of the Latvian Corruption Prevention and Combating Bureau (KNAB). The KNAB's core budget increased in 2016 and 2017.This shows the commitment of Latvia to fighting corruption and avoid political interference with the work of the KNAB. However, the budget of the KNAB continues to be proposed by the Council of Ministers and is approved by parliament annually, weakening independence. Full independence is important so KNAB is perceived to be able to investigate corruption within these institutions. As is the case for competition authorities, budgetary independence should be reinforced by mechanisms reducing government discretion, such as fixed multiannual budget allocations, allocation of fixed revenue sources, for example fees or taxes, or a combination of these (OECD, 2016c).

Many judges are appointed by parliament, which may expose them to political influence. Stronger independence from political influence in the procedures to appoint judges could also improve perceptions of governance. It is welcome that legislation to strengthen the independence of judges is being considered by parliament. There is also scope to strengthen rules on the engagement of lobbyists in the legislative process (Council of Europe, 2016). Broadening access to key social services, notably health services, may also strengthen perceived fairness and thereby willingness to work in the formal economy. 
$\mathrm{ECO} / \mathrm{WKP}(2017) 70$

\section{Creating a more open and competition-friendly regulatory environment}

A transparent and competition-friendly regulatory environment provides the base for Latvia's participation in GVCs and its competitiveness in knowledge intensive value chain activities. An open and efficient trade regime is essential as Latvia relies on imported inputs given its small size. Trade openness also matters because trade costs, both tariffs and costs arising from border procedures or behind-the-border regulations, are magnified within GVCs as goods and services cross several borders (OECD, 2013a).

Latvia has made progress in reducing regulatory barriers to entrepreneurship by making it easier to get licences and permits and by reducing administrative burdens for start-ups. The "silence is consent" rule, which grants firms the right to operate in absence of a formal response from the authority within a given period, has been extended to 17 services. An online one-stop shop has been set up, allowing firms to acquire all information needed for acquiring licences and permits. Also, the time needed to create a business has been reduced. Registration of a company can be done completely online from 2018 .

Funding for the Competition Council, the main organisation implementing competition policy has increased. On the other hand, the Council remains a sub-organisation of the Ministry of Economy and its autonomy over its budget is limited. Also, the Council does not have the statutory power to intervene against public actions which restrict competition, such as anticompetitive municipal regulations, unlike the competition authorities in many other countries (OECD, 2014). Concerns were expressed that municipalities expand their commercial activities and undermine competition by private providers (for example, FICIL, 2013). Granting the Council the authority to intervene against certain anticompetitive acts by municipalities ensures fair competition between State-owned enterprises (SOEs) and private firms. However, such reform would be more credible with complete formal independence from the Ministry of Economy (OECD, 2014). Furthermore, the status of employees as civil servants makes it difficult for the Council to offer competitive compensation to qualified personals.

State-owned enterprises (SOEs) in Latvia enjoy dominant market shares in some network industries namely in electricity and transportation. The government has implemented measures to improve the corporate governance of state-owned enterprises as committed during the OECD accession process. Legislation stipulating the governance framework of SOEs came into force in 2015, introducing the Coordination Institution, which advises the Cabinet and shareholder ministries and institutions on corporate governance. The Coordination Institution is also tasked to increase the transparency of SOEs. It produced the first annual report of SOEs in 2016. Boards of directors were instated in the 12 largest stateowned enterprises by the end-2016. The government should consider extending these measures to all other commercially oriented SOEs, regardless of their size. It has been pointed out that the case for state ownership is unclear in some cases (OECD, 2015b). The government is in process of assessing state ownership of enterprises.

According to the OECD Trade Facilitation Indicator, Latvia's border procedures are close to best practice. However, there is still room to reduce the border transaction costs by delegating some border controls from government agencies to the custom authority and aligning border procedures and formalities with neighbouring countries. Small improvement in border procedures are found to increase significantly the use of imported inputs in producing exports (Moïsé and Sorescu, 2015), an area in which Latvia lags behind its peers (Figure 6). Such improvements are likely to be particularly beneficial for small economies, such as Latvia's.

Costs related to service trade are particularly relevant for Latvia's competitiveness in GVCs, given that services account for 52\% of domestic value added embodied in Latvia's exports. Barriers to service trade are low overall, except in air transport and telecommunications where state ownership is large (Figure 26). In telecommunications, the state holds a controlling share in companies providing fixed and mobile 
telecommunication and internet services. There are also barriers related to the movement of people. For instance, non-EU persons seeking to provide services in Latvia on a temporary basis, for example employees of multinational enterprises transferred to affiliated firms in Latvia, are required to be paid at least as well as local employees. For independent service suppliers the duration of stay is limited to 12 months on their first entry permit.

Figure 26. Barriers to service trade are low overall

OECD Services Trade Restrictiveness Index 1 , scale from 0 to 1 (most restrictive), 2016

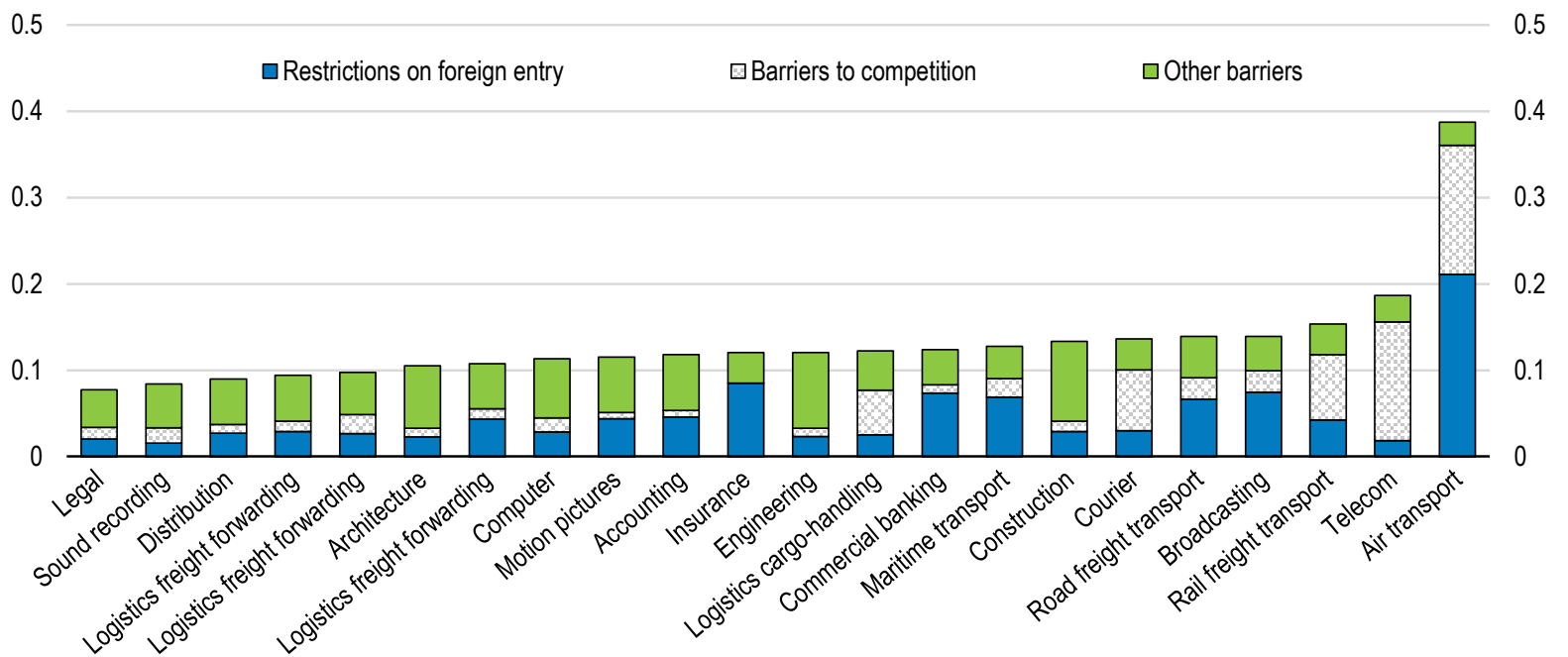

1. They are calculated on the basis of the Service Trade Restrictions Index (STRI) regulatory database over the 35 OECD Members, Brazil, China, Colombia, Costa Rica India, Indonesia, Lithuania, Russia and South Africa. The STRI database records measures on a most-favoured-nations basis. Preferential trade agreements are not taken into account. Air transport and road freight cover only commercial establishment (with accompanying movement of people).

Source: OECD (2017), "Service Trade Restrictions Index by services sector" in OECD Industry and Services Statistics (database).

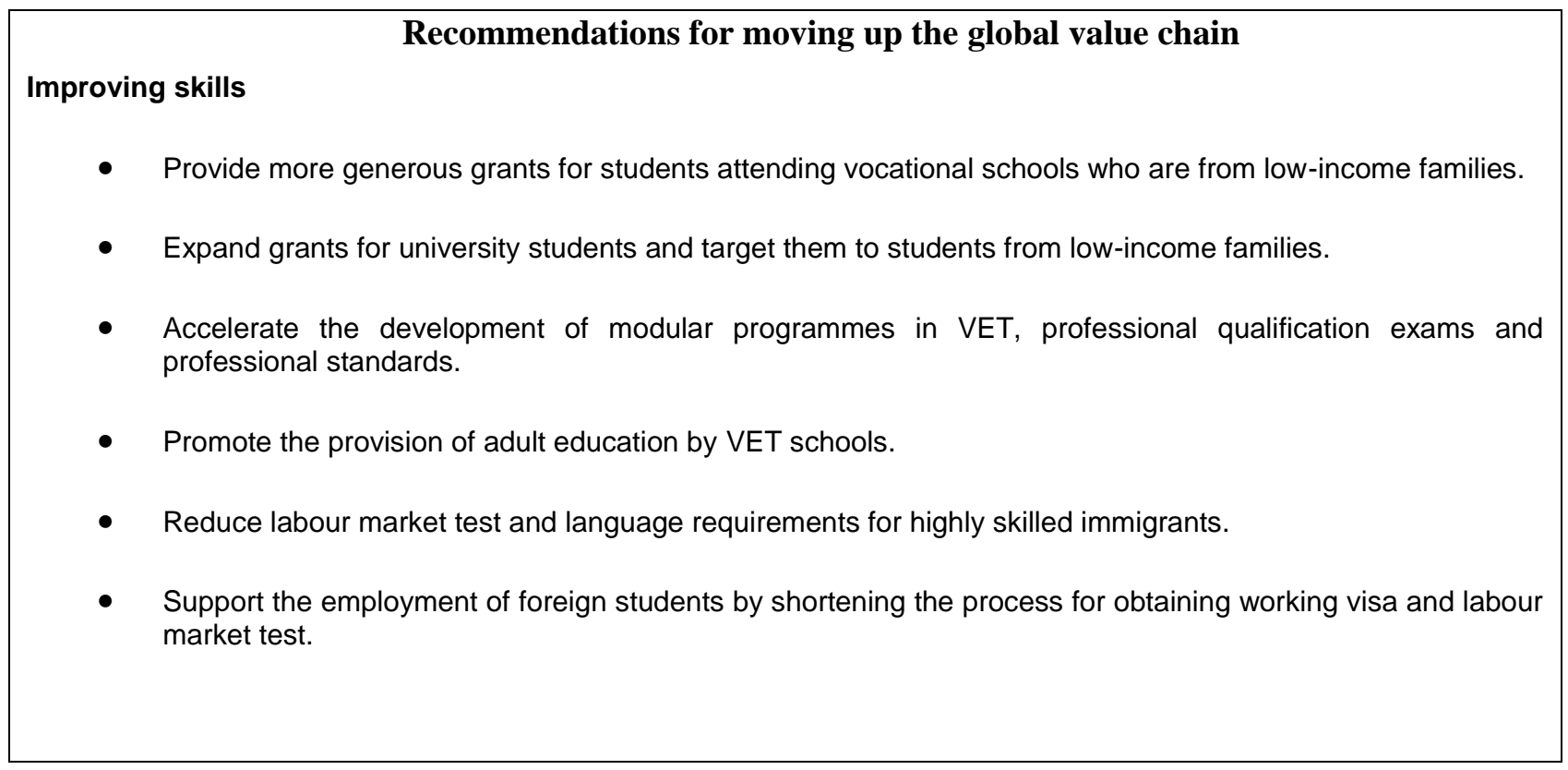


$\mathrm{ECO} / \mathrm{WKP}(2017) 70$

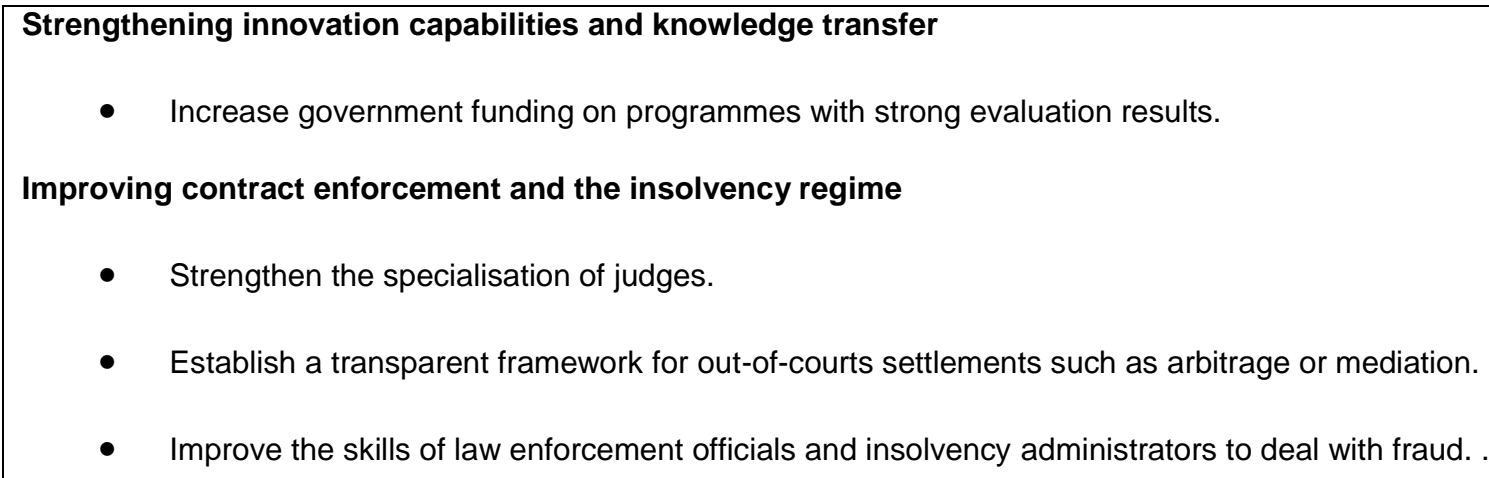

- Increase government funding on programmes with strong evaluation results.

Improving contract enforcement and the insolvency regime

- Strengthen the specialisation of judges.

- Establish a transparent framework for out-of-courts settlements such as arbitrage or mediation.

- Improve the skills of law enforcement officials and insolvency administrators to deal with fraud.

\section{Reducing informality}

- Strengthen the budgetary independence of the Corruption Prevention and Combating Bureau (KNAB).

- Make better use of information and communication technology for tax law enforcement.

- Remove political influence in the appointment of judges.

Improving the business environment

- Strengthen the budgetary independence of the Competition Committee.

- Introduce boards in all commercially oriented state-owned enterprises and clarify the rationale for state ownership.

- $\quad$ Strengthen cooperation with border agencies of neighboring countries by aligning border procedures and formalities.

\section{REFERENCES}

Adalet McGowan, M. and D. Andrews (2016), "Insolvency Regimes And Productivity Growth: A Framework For Analysis", OECD Economics Department Working Papers, No. 1309, OECD Publishing, Paris. DOI: http://dx.doi.org/10.1787/5jlv2jqhxgq6-en

Alfaro, L. (2016) Gains from Foreign Direct Investment: Macro and Micro Approaches. World Bank Economic Review (2016) 1-14.

Amiti, M., Konings, J. (2007). Trade Liberalization, Intermediate Inputs, and Productivity: Evidence from Indonesia. American Economic Review, 97(5): 1611-1638.

Aw, B.Y., Roberts, M.J., Winston, T. (2007), Export Market Participation, Investments in R\&D and Worker-Training, and the Evolution of Firm Productivity, World Economy 83-104. 
Baldwin, R. (2012), "Global Supply Chains: Why They Emerged, Why They Matter and Where They Are Going”, CEPR Discussion Paper, No. DP 9103.

Bank of Latvia (Latvijas Banka) (2016), Euro area bank lending survey of September 2016: main results for Latvia; available at https://www.bank.lv/en/publications-r/euro-area-bank-lending-survey.

Baranovska, I. et al. (2015), VET to work transition - Challenges and Opportunities, National Centre for Education, Riga.

Beņkovskis, K., Bērziņa, S. and Zorgenfreija, L. (2016) Evaluation of Latvia's re-exports using firm-level trade data, Baltic Journal of Economics, 16:1, 1-20, DOI: 10.1080/1406099X.2016.1163891

Beņkovskis, K.,Masso, J., Tkasevs, O., Vahter, P., Yashiro, N. (2017), "Export and productivity in Global Value Chain: Evidences from Latvian and Estonian firms" OECD Economics Department Working Paper, forthcoming.

Bernard A. B., Jensen, B.J.(1999) “Exceptional exporter performance: cause, effect, or both?” Journal of International Economics, Vol. 47, pp. 1-25,

Bustos, P. (2011) Trade Liberalization, Exports, and Technology Upgrading: Evidence on the Impact of MERCOSUR on Argentinian Firms. American Economic Review, 101(1): 304-40.

Central Statistic Bureau (2016) Innovation in Latvia (in Latvian) http://www.csb.gov.lv/sites/default/files/nr_37_inovacijas_latvija_16_00_lv.pdf

Coe, D.T., E. Helpman, A.W. Hoffmaister (2009) International R\&D spillovers and institutions, European Economic Review, Elsevier, vol. 53(7), pages 723-741, October.

Council of Europe (2016) "Corruption prevention in respect of members of parliament, judges and prosecutors." Fourth evaluation round. Interim compliance report Latvia.

Dasgupta, K. (2012) Learning and knowledge diffusion in a global economy. Journal of International Economics 87:2323-336.

Online publication date: 1-Jul-2012.Daude, C. H. Gutiérrez and A. Melguizo (2012), "What drives tax morale?" OECD Development Centre, Working Paper No. 315.

De Boer, H. et al. (2015), Performance-based funding and performance agreements in fourteen higher education systems, Center for Higher Education Policy Studies Universiteit Twente, Enschede.

Dedrick, J., Kraemer,K.L., Linden,G. (2010) "Who profits from innovation in global value chains?: a study of the iPod and notebook PCs." Industrial and Corporate Changes Volume 19 Issue 1 February 2010: $81-116$

De Loecker, J. (2007) “Do exports generate higher productivity? Evidence from Slovenia” Journal of International Economics

European Commission (2016a) European Innovation Scoreboard 2017

European Commission (2016b) Country Report Latvia 2016, Commission Staff Working Document, The European Commission, Brussel 
Essaji, A, Fujiwara, K. (2012) “Contracting institutions and product quality" Journal of Comparative Economics, 40 (2), pp. 269-278

European Parliament (2015), The Policy on Gender Equality in Latvia. In-depth analysis.

Feenstra, R.C., Hanson, G.H. (2004) "Intermediaries in Entrepôt Trade: Hong Kong Re-Exports of Chinese Goods". Journal of Economics and Management Strategy, vol. 13, No. 1, March, pp. 3-35.

FICIL (2013) Position Paper on Waste Management Policy, Foreign Investors Council in Latvia, Riga. http://www.ficil.lv/f/13\%2005\%2026_Waste_ENG.pdf

FICIL (2016) FCIL Insolvency Abuse Report 2016, Foreign Investors Council in Latvia, Riga.

Gaveika, M., K. Skrūzkalne (2012), Gender wage gap in Latvia, Stockholm School of Economics Riga Student Research Papers2012: 6 (145)

Gereffi, G. (1999), "International trade and industrial upgrading in the apparel commodity chain" Journal of International Economics 48(1), 37-70

Guillemette, Y., Turner, D., Kopoin, A., de Mauro, A. (2017) “A revised approach to productivity convergence in long-term scenarios" ", OECD Economics Department Working Papers, No. 1385, OECD Publishing, Paris.

Government of Latvia (2016), Implementation plan for Adult Education Governance model (2016-2020), Government of Latvia, Riga, http://likumi.lv/ta/id/281992-par-pieauguso-izglitibas-parvaldibasmodela-ieviesanas-planu-2016-2020-gadam.

Henson, S. and J. Humphrey (2010) "Understanding the Complexities of Private Standards in Global Agri-Food Chains as They Impact Developing Countries," The Journal of Development Studies, $46: 9,1628-1646$

Hoekman, B., Javorcik, B.S. (2006), Global Integration and Technology Transfer, Plagrave Macmillian and the World Bank,Washington D.C.

Hsieh, C.T. (2015), "Policies for productivity growth", OECD Productivity Working Papers, 2015-03, OECD Publishing, Paris.

ISGEP (International Study Group on Exports and Productivity), 2008, "Understanding Cross-Country Differences in Exporter Premia: Comparable Evidence for 14 Countries" Rev World Econ Vol.1, 144: 596.

Kaplinsky, R. and M. Morris, (2002), "A Handbook for Value Chain Research”, Institute of Development Studies, www.ids.ac.uk/ids/global/pdfs/VchNov01.pdf

Levchenko, A.A. (2007) "Institutional quality and international trade" Review of Economic Studies, 74 (3) (2007), pp. 791-819

Manova, K., Yu, Z. (2016), How firms export: Processing vs. ordinary trade with financial frictions, Journal of International Economics 100 (2016) 120-137.

Masso, J., Rõigas, K. and Vahter, P. (2015). Foreign market experience, learning by hiring and firm export performance. Review of World Economics/Weltwirtschaftsarchiv, 151(4), 659-686. 
Masso, J., Vahter, P. (2016), "Knowledge Transfer from Multinationals through Labour Mobility: Learning from Export Experience", University of Tartu, Faculty of Economics and Business Administration Working Paper No. 99.

Melitz, M. (2003) "The Impact of Trade on Intra-Industry Reallocations and Aggregate Industry Productivity.” Econometrica 71: 1695-1725.

Miroudot, S. and C. Cadestin (2017), "Services In Global Value Chains: From Inputs to Value-Creating Activities", OECD Trade Policy Papers, No. 197, OECD Publishing, Paris. http://dx.doi.org/10.1787/465f0d8b-en

MoES (2014), Education Development Guidelines 2014-2020, Ministry of Education and Science, Riga, http://m.likumi.lv/doc.php?id=266406.

Moïsé, E. and S. Sorescu (2015), "Contribution of Trade Facilitation Measures to the Operation of Supply Chains", OECD Trade Policy Papers, No. 181, OECD Publishing, Paris. http://dx.doi.org/10.1787/5js0bslh9m25-e

OECD (2013a), Interconnected Economies: Benefiting from Global Value Chains, OECD Publishing, Paris. DOI: http://dx.doi.org/10.1787/9789264189560-en

OECD (2013b), Supporting Investment in Knowledge Capital, Growth and Innovation, OECD Publishing, Paris. DOI: http://dx.doi.org/10.1787/9789264193307-en

OECD (2014), Accession Review of Latvia, OECD Competition Committee, DAF/COMP/ACS(2014)3

OECD (2015a), The Innovation Imperative: Contributing to Productivity, Growth and Well-Being, OECD Publishing, Paris. DOI: http://dx.doi.org/10.1787/9789264239814-en

OECD (2015b), OECD Economic Surveys: Latvia 2015, OECD Publishing, Paris. http://dx.doi.org/10.1787/9789264228467-en.

OECD (2016a), Education in Latvia, Reviews of National Policies for Education, OECD Publishing, Paris, http://dx.doi.org/10.1787/9789264250628-en.

OECD (2016b), OECD Reviews of Labour Market and Social Policies: Latvia 2016, OECD Publishing, Paris. http://dx.doi.org/10.1787/9789264250505-en

OECD (2016c), Independence of Competition Authorities - From Design to Practices

OECD (2017), Economic Policy Reforms 2017: Going for Growth, OECD Publishing, Paris. http://dx.doi.org/10.1787/growth-2017-en

Putnins, T., Sauka, A. (2017) Shadow Economy Determinants and Impact Assessment in Latvia, Lithuania and Estonia. OECD: Paris.

Roberts, M., \& Tybout, J. (1997). The Decision to Export in Colombia: An Empirical Model of Entry with Sunk Costs. The American Economic Review, 87(4), 545-564.

Schneider, F. (2016). "Size and development of the shadow economy of 31 European and 5 other OECD countries from 2003 to 2016: Different developments." Unpublished manuscript. 
Torgler, B. and F. Schneider and J. Kepler (2007), "Shadow Economy, Tax Morale, Governance and Institutional Quality, A Panel Analysis”, IZA Discussion Paper No. 2563, January 2007.

Turk, P., L. Kraut, S. Anspal, E. Kallaste (2010), "Gender Pay Gap in Estonia: Policy Recommendations". Mimeo.

Wagner, J. (2007). "Exports and Productivity: A Survey of the Evidence from Firm-level Data," The World Economy, Wiley Blackwell, vol. 30(1), pages 60-82, 01. 